\title{
Preustroj sigurnosnoga sustava banske Hrvatske 1915. godine
}

\author{
MIROSLAV KOTA \\ Zagreb, Hrvatska \\ miroslavkota@gmail.com
}

\begin{abstract}
Druge godine Velikoga rata preustrojava se sigurnosni sustav banske Hrvatske. Tom prilikom Središnja defenzivno doglasna služba, koja je obavljala poslove tajne državne policije, kao samostalno tijelo pri Zemaljskoj vladi postaje njezinom sastavnicom, ulazeći u sastav novoosnovanoga Odsjeka IV-B za pogranična redarstvena satništva Odjela za unutarnje poslove Zemaljske vlade. Razlozi preustroja, pored političkih, osobito sukoba vojnih i civilnih vlasti, bili su i raznovrsni funkcionalni. Zahvaljujući potrebama obrane Zemaljska vlada preko te službe počinje dobivati i dio financijskih podataka koji su joj do tada bili nedostupni jer su izlazili iz okvira autonomnih poslova banske Hrvatske. U članku se na temelju arhivskoga gradiva i relevantne historiografske literature te dijelom i tiska predstavlja i analizira preustroj sigurnosnoga sustava 1915. godine.
\end{abstract}

Ključne riječi: Prvi svjetski rat; sigurnosni sustav; banska Hrvatska; preustroj; Središnja defenzivno doglasna služba; Austro-Ugarska

\section{Uvod}

Tijekom ljeta 1915. dolazi do preustroja u Zemaljskoj vladi, i to u njezinu Odjelu za unutarnje poslove, vezano za djelovanje sigurnosnoga sustava. Preustroj je u historiografiji primijećen, ${ }^{1}$ ali se nije ulazilo u njegovu dublju raščlambu. Pritom je dio banskih odluka bio nepoznat, pa su povjesničari morali rekonstruirati dio događaja prema podacima navedenim u drugim dokumentima. Do sada se mislilo da je glavni razlog preustroja bio sukob civilnih i vojnih vlasti u Zagrebu, koji je isprovocirao smjenu zagrebačkoga vojnog zapovjednika generala Scheurea i reformu Zemaljske vlade. Premda je to bio jedan od razloga preustroja, o njemu se u dokumentima ne govori. Na temelju poduzetih istraživanja ovim radom predstavit ćemo razloge preustroja, kao i do sada nepoznatu bansku naredbu.

1 BEUC, Povijest institucija državne vlasti Kraljevine Hrvatske, Slavonije i Dalmacije, 259. 


\section{Razlozi preustroja}

Razloge preustroja možemo podijeliti na funkcionalne, koji su izvirali iz potrebe rada samoga sigurnosnog sustava, i političke. ${ }^{2}$ Funkcionalni razlozi odnosili su se na želju za postizanjem boljih rezultata rada sigurnosnoga sustava, bolje prikrivanje rada Središnje defenzivno doglasne službe $(\mathrm{SDDS})^{3}$ kao tajne službe unutar vladinih institucija, osiguravanje asistencije SDDS-u pomoću detektiva pograničnoga redarstvenog satništva, pa i drugih redarstvenih povjereništava, te osiguravanje financijskih sredstava za rad službe.

Vezano za organizacijska pitanja, austrougarsko Vrhovno vojno zapovjedništvo (AOK, od njem. Armeeoberkommando) ${ }^{4}$ dalo je 6. ožujka 1915. određene upute, odnosno postavilo pitanja SDDS-u Zagreb radi dobivanja jasne slike o tada postojećem sveukupnom protuobavještajnom aparatu na bojištu, ali i u pozadini. U tom smislu bilo je potrebno skicirati organizacijsku podjelu institucija u obavještajnom radu i njihovu odgovornost radi prepoznavanja mogućih područja nepokrivenih zaštitom. U tom smislu AOK se interesirao za ustroj protuobavještajne službe i teritorijalnu nadležnost, za suradnju s civilnim vlastima, oružništvom i financijama, za cenzuru pošte - kako se provodila u postrojbama i njihovim trainovima (komorama, od franc. train), za etapna područja, pozadinu, promet željeznicom, za pisma, brzojave, časopise, pakete i sl. Pored toga AOK je zanimao nadzor željezničkoga prometa u odnosu na civilne i vojne osobe pomoću redarstvenih agenata u samim vlakovima ili preko

2 Za političke prilike u banskoj Hrvatskoj uoči i na početku Prvoga svjetskog rata preporučujemo: MATIJEVIĆ, Ljudi, stranke, događaji; MATIJEVIĆ, Između sna i jave; MATIJEVIĆ, $U$ sjeni dvaju orlova; MATIJEVIĆ, Lučonoše ili herostrati?; HORVAT, Politička povijest Hrvatske, sv. I-II; VALENTIĆ, ČORALIĆ, Povijest Hrvata, knj. 2: Od kraja 15. stoljeća do kraja Prvoga svjetskog rata; BILANDŽIĆ, Hrvatska moderna povijest; S. PRIBIĆEVIĆ, Diktatura kralja Aleksandra; H. MATKOVIĆ, Svetozar Pribićević; GANZA-ARAS, Politika „novog kursa”; ĐORĐEVIĆ, „Pokušaji srpsko-ugarske saradnje i zajedničke akcije 1906. godine”, 353-384; S. MATKOVIĆ, Čista stranka prava 1895.-1903.; Stenografski zapisnik o glavnoj raspravi protiv Adama Pribićevića i 52 druga; GROSS, Vladavina Hrvatsko-srpske koalicije 1906-1907; GROSS, „Hrvatska uoči aneksije Bosne i Hercegovine”, 153-269; BULIĆ, „Savez Hrvatsko-srpske koalicije i bana Ivana Skerlecza”, 23-47; BULIĆ, „Ivan Skerlecz Lomnički 1913.-1917”; BULIĆ, „Politika Hrvatskosrpske koalicije uoči Prvoga svjetskog rata”, 415-453; GABELICA, „Političke prilike u Banskoj Hrvatskoj na početku Prvoga svjetskog rata”, 177-197; GABELICA, „Zagrebačka veleizdajnička parnica 1909. godine”, 131-157; ŠIDAK, „Hrvatsko pitanje u Habsburškoj monarhiji I i II”, 101-121 i 175-194; ŠIDAK, „Jugoslavenska ideja u hrvatskoj politici do I. svjetskog rata”, 65-84; SUPPAN, Oblikovanje nacije u građanskoj Hrvatskoj; KRIZMAN, Hrvatska u Prvom svjetskom ratu; A. PRIBIĆEVIĆ, Moj život, a o političkim prilikama u Monarhiji: RAUCHENSTEINER, The First World War.

3 O osnutku SDDS-a vidi detaljnije: KOTA, „Uspostava i rad sigurnosno-obavještajnog sustava banske Hrvatske 1914. godine”, 441-464.

4 Operativno je AOK vodio načelnik Glavnoga stožera general Franz Conrad, a formalno je uime cara i kralja vrhovni zapovjednik bio nadvojvoda Friedrich. Godine 1917. načelnikom Glavnoga stožera postao je general Artur Arz. Tijekom rata sjedište AOK-a premještalo se ovisno o razvoju vojne situacije iz galicijskoga (danas Poljska) Przemyśla u šleski (danas Češka) Teschen i naposljetku u Baden kod Beča. Na potonje je osim talijanskoga ulaska u rat utjecala i promjena vladara. Vidi: RONGE, Kriegs- und Industrie Spionage i RAUCHENSTEINER, The First World War. 
kolodvorskih nadzornih postaja, prijenos informacija npr. plakatiranjem, mogućnost slobodnoga pristupa neovlaštenih osoba, osobito civila, vojnim postrojbama ili prostorima, mogućnost kontakta stranaca i osoba neutvrđenoga identiteta ili nedovoljno sigurnosno provjerenih te suradnja s vojnim postrojbama u pojedinim mjestima. Za sva spomenuta i druga opažanja koja nisu bila izrijekom spomenuta SDDS je trebao prikupljati informacije i od doušnika. ${ }^{5}$

Žiga Maravić, voditelj Redarstvenoga odsjeka Odjela za unutarnje poslove Zemaljske vlade, ujedno po položaju i upravitelj SDDS-a, 22. travnja 1915. odgovorio je AOK-u da je protuobavještajna služba organizirana u skladu s naredbom bana od 6. lipnja 1914., ${ }^{6}$ čiji je primjerak i dostavio. Naglasio je da su u području nadležnosti Zemaljske vlade sve političke oblasti i redarstvena tijela surađivali sa SDDS-om u protuobavještajnom radu. Što se tiče financijskih tijela, SDDS s njima nije dolazio u doticaj (zbog nadležnosti u podjeli poslova iz Hrvatsko-ugarske nagodbe). Suradnju s oružništvom ocijenio je neznatnom. Po našem dojmu, Maravić je to prestrogo ocijenio jer ima dosta spisa $^{7} \mathrm{~s}$ određenim angažmanom oružništva. Doduše, Maravić je dodao da su od početka rata oružničke postaje stavljene pod Vojno zapovjedništvo, koje su onda i izravno izvješćivale o različitim događajima. S krilnim zapovjedništvima (njem. Flügelkommando) oružništva u Zemunu i Mitrovici uopće nije bilo suradnje od početka rata. Suradnja s poštanskom cenzurom postojala je do tada samo ako se Središnji ured interesirao za neku stvar, što je bilo iznenađujuće.

Nadzor nad vlakovima uzurpirale su vojne vlasti, pa su čak i redarstveni agenti znali biti izloženi samovolji i bezobzirnom postupanju vojnika. Samom upravitelju SDDS-a Zagreb Maraviću nije bilo dopušteno ni uz predočenje službene iskaznice pristupiti zagrebačkom kolodvoru radi kontrole. Jednostavno mu ondje nazočni vojnici nisu dopustili prolaz jer nisu imali takve upute. ${ }^{8}$ Očito je Maravić mogao ući na kolodvor jedino kao putnik, i to ako je imao putnu kartu. Za prijenos informacija (plakatiranje i sl.) naveo je da se strogo nadzirao. Nadzor nad pristupom nepozvanih i sličnih osoba vojnim postrojbama i prostorima bio je u nadležnosti vladinih povjerenika, koji su to provodili zajedno s Vojnim zapovjedništvom snaga za Balkan (njem. Balkanstreitkräfte). Da bi se poboljšao rad, Maravić je držao da bi prije svega oružnička krilna zapovjedništva koja su ležala na pravcu djelovanja Balkanske vojske svoja izvješća, bez obzira na vojni lanac zapovijedanja, pri sumnji na uhodarstvo

5 HR-HDA-79-UOZV, Središnja defenzivno doglasna služba (dalje: SDDS), kut. 5693, spis 518/15, dok. br. 5466 .

6 „Naredba o djelokrugu i organizaciji središnjeg ureda za defenzivno doglasnu službu i glavnih mjesta u Zagrebu, Osijeku, Mitrovici, Zemunu i Sušaku” pod brojem 86/res., koju je donio ban Ivan Skerlecz 6. lipnja 1914., HR-HDA-79-UOZV, SDDS, kut. 5688, spis 86/14. Naredba je predstavljena u: KOTA, „Uspostava i rad sigurnosno-obavještajnog sustava banske Hrvatske 1914. godine", 446-450.

7 HR-HDA-79-UOZV, SDDS, kut. 5687-5693 (od lipnja 1914. do travnja 1915.), ali i dalje.

8 Iz njemačkoga izvornika: Der unterfertigte leiter der Zentralstelle konnte bis jetzt auf den Banhof in Zagreb nicht gelangen obwohl er mit einer Legitimation versehen ist. Die soldaten die einseitig unterwiesen werden, lassen einen ganz einfach nicht passieren. 
(špijunažu) morala slati SDDS-u Zagreb, bilo izravno bilo preko zagrebačkoga oružničkog zapovjedništva. Za cenzuru pisama Maravić je odgovorio da je pretežno bila koncentrirana na vojna pitanja, „što je i razumljivo, no morala bi stupiti u vezu i sa SDDS-om, što je sigurno lako izvedivo”. Predložio je ustupanje uhodarski sumnjive korespondencije vojnoga predstavnika u cenzurnom povjerenstvu vladinu predstavniku ili izravno SDDS-u. Na taj način Središnji ured mogao bi lakše doći u posjed informacija bitnih za protuobavještajni rad. Zapovjednike kolodvora trebalo je poučiti o ovlasti vladinih činovnika i redarstvenih agenata za ulazak na perone nakon što bi se predstavili svojim iskaznicama. Maravić je nadalje smatrao da je nedopustivo da je Srijem, koji se nalazio u vojnom operacijskom području od izbijanja rata, gotovo cijeli ispao iz nadležnosti SDDS-a, a bio je važan s protuobavještajne točke gledišta. U Srijemu je bilo opasnih čimbenika koje SDDS još nije evidentirao. Ako takve osobe ne bi bile uvedene u evidencije SDDS-a, to bi se nastavno pokazalo opasnim zbog mogućnosti uhodarstva u ostatku banske Hrvatske, što nije bilo poželjno. Pored toga Maravić je primijetio da bez dotacija SDDS neće moći uspješno poslovati. Vlada nije imala dovoljno vlastitih sredstava, pa je molio Ratno ministarstvo neka povede računa o tome. „Glede toga da bi Središnji ured morao raspolagati mrežom vlastitih doušnika, bez novčanih sredstava kojima bi se oni nagradili ne može se očekivati ni uspjeh u radu”, završava Maravić u prilično otvorenom, ponegdje i oštrom očitovanju. ${ }^{9}$

$\mathrm{Na}$ Maravićeve primjedbe AOK je odgovorio SDDS-u neizravno 3. srpnja 1915., i to preko Vojnoga zapovjedništva Zagreb, koje je javilo SDDS-u da su u skladu s uputom načelnika Glavnoga stožera br. 4444 iz 1914. osnovani središnji uredi Defenzivno doglasne službe (njem. Zentralstellen für den defensiven Kundschaftsdienst) - SDDS Zagreb i VHK ${ }^{10}$ Budimpešta (pored središnjih ureda u Beču i Sarajevu), s njima podređenim glavnim uredima. Vrhovno vojno zapovjedništvo bilo je svjesno da je banskom naredbom od 6. lipnja 1914. organiziran SDDS u banskoj Hrvatskoj. Središnji ured morao je voditi evidenciju o svim za uhodarstvo sumnjivim osobama, a u svemu drugome postupati prema banskoj naredbi. Vojno zapovjedništvo istaknulo je da su vojna tijela, oružništvo i financijska straža upoznati s osnutkom SDDS-a Zagreb kao središnjega ureda te da su bili obvezni, svaki u svojem polju odgovornosti, pružiti sve informacije vezane uz uhodarstvo Središnjem uredu bilo na vlastiti poticaj, bilo po njegovu zahtjevu. Budimpeštanskom VHK-u informacije je dostavljala podređena financijska straža u banskoj Hrvatskoj preko nadležnoga ministarstva, a SDDS-u Zagreb o svim drugim pitanjima ostala tijela i oružništvo. Sva pošta namijenjena SDDS-u morala se radi čuvanja tajnosti podataka zatvarati u dvije omotnice, pri čemu se na vanjsku pisala adresa Kgl. kroat.slav.dalm. Landesregirung. Innere Abt. (Polizeisektion res) in Zagreb, a na unutarnju, u

9 HR-HDA-79-UOZV, SDDS, kut. 5693, spis 518/15.

${ }_{10}$ Kratica mađarskoga Védelmi Hirszerzöközpont. Prevodna pisarnica Zemaljske vlade to je prevodila kao „Obrambena doglasna centrala”. 


\section{koju se ulagao dopis, An SDDS Zagreb, Zur eigenhändigen eröffnung durch den Chef..$^{11}$}

Na pitanje nemogućnosti ulaska službenih osoba SDDS-a na kolodvor vojska se tada nije osvrnula, ali je iz kasnijih događaja vidljivo da je detektivima u međuvremenu bio dopušten ulazak sa službenim ispravama u prostor željeznice, pa i kontrola putnika u samim vlakovima, a što se rat više primicao kraju, sve više i na zahtjev same vojske. Nešto poslije Maravić je, očito postupajući po usmenoj uputi, zatražio od Vojnoga zapovjedništva u Zagrebu ispravu koja bi $\mathrm{mu}$ omogućila neometani pristup željezničkim kolodvorima u svrhu nadgledanja rada podređenih tijela, a vojne vlasti zaista su mu izdale takvu ispravu 23. kolovoza 1915. godine. ${ }^{12}$

Radi poboljšanja suradnje u nadzoru željezničkoga prometa u odnosu na civilne i vojne osobe Vojno zapovjedništvo Zagreb obavijestilo je 19. rujna 1915. Maravića da su zapovjedništva kolodvora i kolodvorski obavještajni časnici upućeni da o svakom slučaju uhićenja izvijeste i SDDS. ${ }^{13}$

Pored novčanih sredstava koja su se za rad SDDS-a osiguravala financijskim sredstvima proračunom namijenjenim redovnom radu Odsjeka za pogranična redarstvena satništva Odjela za unutarnje poslove Zemaljske vlade, SDDS je počeo uživati i novčane dotacije Evidenzbureaua ${ }^{14}$ iz vojnoga tajnog fonda u iznosu od 52.000 kruna godišnje, namijenjene operativnim troškovima i za isplate konfidentima. ${ }^{15}$

11 HR-HDA-79-UOZV, SDDS, kut. 5693, spis 1207/15 (uloženo u spis 518/15), dok. br. 803/1, u slobodnom prijevodu s njemačkoga: „Kr. hrvatsko-slavonsko-dalmatinska zemaljska vlada, Unutarnji odjel, Redarstveni odsjek, rezervatno (povjerljivo) ... SDDS-u Zagreb, vlastoručno otvara šef."

12 HR-HDA-79-UOZV, SDDS, kut. 5696, spis 1681/15 (uloženo u spis 1709/15).

13 HR-HDA-79-UOZV, SDDS, kut. 5695, spis 2027/15 (uloženo u spis 1682/15).

14 Austrougarska vojna obavještajna služba, ustrojstvena jedinica Glavnoga stožera u Beču, ujedno tijekom Prvoga svjetskog rata zadužena za koordinaciju i nadzor rada središnjih ureda civilne defenzivno doglasne službe. Ime potječe od vođenja vojne kadrovske evidencije kao primarne zadaće, kojoj su poslije dodani obavještajni poslovi i vođenje evidencije o njima, a kadrovski su poslovi izdvojeni. Evidenzbureau se ustrojstveno od 1907. sastojao od sljedećih odjela: obavještajnoga (operativnoga), koji je pokrivao i protuobavještajne zadatke, te po svojoj naravi analitičkih odjela: ruskoga, talijanskoga, balkanskoga, njemačkoga, francuskoga i engleskoga. Teritorijalno su mu bili podređeni glavni uredi u Grazu, Innsbrucku, Temišvaru, Zagrebu, Sarajevu, Zadru, Lembergu (Lavovu), Krakovu i Przemyślu, a u svakom vojnom zboru pri stožeru zapovjedništva postojao je obavještajni odjel te u diviziji časnik za obavještajne poslove. Tijekom vremena u Evidenzbureauu su ustrojeni još i fotografski, manipulativni (logistički), fortifikacijski i topnički odjel, odjel za prisluškivanje radio-brzojava, politički odjel, odjel za gospodarstvo, industriju i znanost te promidžbeni odjel. Za vrijeme rata vrlo uspješno prisluškivanje i dešifriranje brzojavnih radio-poruka obavljalo se preko stacionarnih prislušnih radio-postaja u Puli, Sarajevu, Petrovaradinu, Mostaru, Kotoru, Baru i Skadru, a na talijanskom i ruskom bojištu koristile su se i prijenosne prislušne radio-stanice, koje su se u počast austrougarskom (i hrvatskom) izumitelju tada popularne olovke kodno nazivale „Penkalama”. Tijekom povijesti i dva Hrvata vodila su Evidenzbureau: Emil Woinovich (Vojnović) von Belobreska (1892. - 1896.) i Oskar Hranilovic (Hranilović) von Czvetassin (1913. - 1917.). RONGE, Kriegs- und Industrie Spionage, 27, 56, 200, 219 i 275.

15 Isto, 193. 


\section{Politički razlozi preustroja}

Što se tiče političkih razloga preustroja, osobito u pitanju odnosa hrvatske vlasti prema Hrvatsko-srpskoj koaliciji (HSK/Koalicija), možemo se u cijelosti pridružiti zaključku koji je iznio Gabelica, ${ }^{16} \mathrm{u}$ smislu da se na početku Prvoga svjetskog rata HSK kao saborska većina našao uz vlast koju su obnašali starounionistički elementi na čelu s banom Skerleczom. Svojim djelovanjem u hrvatskom Saboru Koalicija je davala legitimitet velikomađarskoj politici ugarske vlade. Na početku rata, uvođenjem izvanrednih mjera u banskoj Hrvatskoj, budući da je ban dobio i zakonodavne ovlasti, Koalicija je potpuno prestala aktivno participirati u vlasti, ali je ostala vladajućom većinom lojalnom Budimpešti. $U$ to vrijeme vojne vlasti, koje su izbijanjem rata i same dobile iznimne ovlasti, optuživale su civilnu vlast u Hrvatskoj da štiti od progona zbog veleizdaje Srbe i srbofilske čimbenike u Hrvatskoj.

Za većinu bi se istaknutih članova Koalicije pouzdano moglo reći da su sve do izbijanja rata, koji je među ostalim izbio i zbog srbijanskih težnji za ostvarenjem velikosrpskoga nacionalno-političkog programa, bili u vezi s institucijama koje su nedvojbeno počivale na velikosrpskim temeljima. Civilna vlast u Hrvatskoj na osnovi tih veza ne samo da nije pokretala veleizdajničke parnice, nego osumnjičene nije htjela pozvati ni na političku odgovornost i odreći se kompromitirane Koalicije. Umjesto toga intervenirala je u korist osumnjičenih (Većeslava Wildera, Živka Bertića, Svetozara i Valerijana Pribićevića, Srđana Budisavljevića, Đure Šurmina) ${ }^{17}$ da bi spriječila raspad Koalicije, koja je bila jamac režimu da će banska Hrvatska ostati pod gospodarsko-političkom dominacijom Ugarske. Drugim riječima, civilna je vlast u Hrvatskoj tijekom rata sa Srbijom štitila velikosrpske elemente u Hrvatskoj da bi osigurala opstanak velikomađarske državne ideje. Spregu velikomađarske i velikosrpske politike u hrvatskim zemljama Monarhije svojedobno je primijetio i Ivo Pilar, koji je tu spregu i optužio za destrukciju Monarhije,

16 GABELICA, „Političke prilike u Banskoj Hrvatskoj na početku Prvoga svjetskog rata”, 192.

17 Od navedenih je jedino Srđan Budisavljević proveo dulje vrijeme u internaciji - 18 mjeseci, i naposljetku je kažnjen, ali blagom kaznom od osam mjeseci zatvora, što je po žalbi ublaženo na šest, ali ne zbog veleizdaje nego zbog zločinstva ometanja javnoga mira - širenja velikosrpske propagande. Kaznu je najvećim dijelom izdržao u zdravstvenom sanatoriju. Svetozar Pribićević bio je u internaciji samo nekoliko mjeseci 1914., a ujesen iste godine završio je kao vojnik u logističkoj postrojbi u Budimpešti, u kojoj je ostao do pretkraj 1917., najveći dio vremena na zdravstvenoj poštedi. Dokaz da je tome tako činjenica je da je Svetozar Pribićević već 23. studenog 1914. slobodan, dakle pušten iz internacije, doputovao iz Budimpešte i posjetio brata Valerijana te Srđana Budisavljevića, obojicu još interniranu pri Sudbenom stolu s dozvolom Redarstvenoga povjereništva u Zagrebu. To je izazvalo žučne reakcije na relaciji SDDS - Sudbeni stol - Redarstveno povjereništvo - Odjel za pravosuđe Zemaljske vlade. HR-HDA-79-UOZV, SDDS, kut. 5690, spis. 859/14, br. 232. 
a ne zaostaje ni Ronge u svojim memoarima. ${ }^{18}$ Pored toga Ronge ${ }^{19}$ je 1915. razgovarao $\mathrm{s}$ Tiszom ${ }^{20}$ o različitim iredentističkim opasnostima za Monarhiju, no ugarski ministar predsjednik umanjivao je njihovu opasnost, smatrajući da im se svakako daje preveliko značenje, te je otklonio potrebu planiranoga i jedinstvenoga djelovanja obje polovice Monarhije s protumjerama koje je zagovarao AOK prihvaćajući Sarkotićevo ${ }^{21}$ mišljenje iz proljeća 1915. godine.

18 PILAR, Južnoslavensko pitanje, 282-288; BULIĆ, „Savez Hrvatsko-srpske koalicije i bana Ivana Skerlecza”, 28; GABELICA, „Političke prilike u Banskoj Hrvatskoj na početku Prvoga svjetskog rata”, 192-193. Ronge navodi da je početkom rata „u Hrvatskoj-Slavoniji situacija bila teška jer je Budimpešta štitila prosrpsku politiku bana suprotno svim pokazateljima veleizdajničkoga gibanja na koje su upozoravale vojne vlasti”, zatim da su „politički centri moći (u Budimpešti) podržavali svoje srpske političke prijatelje”, kao i prema slobodnom prijevodu sarkastične primjedbe zagrebačkoga vojnog zapovjednika da je „svaki Srbin uvijek Srbin i da bi bilo lakše pretvoriti psa u mačku nego Srbina u [Monarhiji] lojalna građanina” (daß jeder Serbe eben ein Serbe sei und daß es eher gelänge, aus einem Hund eine Katze zu machen, als aus einem Serben einen loyalen Staatsbürger). RONGE, Kriegs- und Industrie Spionage, 98-99.

19 Maximilian Ronge (1874. - 1953.), austrougarski vojni časnik i obavještajac. Do 1907. na različitim dužnostima u vojnim postrojbama, kada nastupa na službu u Evidenzbureauu, gdje se počinje baviti operativnim poslovima, koji su tada uz obavještajne aktivnosti u inozemstvu obuhvaćali i protuobavještajne, osobito radi zaštite vojske. Godine 1913. sudjelovao je u otkrivanju izdaje pukovnika Alfreda Redla, bivšega šefa operative Evidenzbureaua, a tada zapovjednika praškoga vojnog zbora, koji je surađivao s Rusima. Ronge vodi operativni rad vojne obavještajne službe do 1917., kada postaje šefom Evidenzbureaua umjesto dotadašnjega general-bojnika Oskara Hranilovića. Osim za upravljanje svim aspektima rada vojne obavještajne službe, na tom mjestu bio je zadužen i za koordinaciju rada civilne defenzivno doglasne službe u cijeloj Monarhiji. Promaknut je u čin general-bojnika. Padom Monarhije raspoređen je za šefa odjela državnopolicijskih poslova grada Beča, a poslije zamjenika načelnika vladina ureda za povrat austrijskih ratnih zarobljenika i civilnih interniraca iz inozemstva. Umirovljen 1932., no reaktiviran kao šef austrijske državne policije 1933. i stavljen pod nadležnost ureda saveznoga kancelara Engelberta Dollfußa. Nije uspio spriječiti ubojstvo Dollfußa 1934., ali je ipak spriječio pronacistički državni udar, no zbog razvoja vanjskopolitičkih događaja (političkoga približavanja Njemačke i Italije) nije mogao zaustaviti njemački Anschluss Austrije. Nijemci su ga zatvorili u koncentracijski logor Dachau. Nakon molbe za pomoć šefu njemačke vojne obavještajne službe Abwehra admiralu Wilhelmu Canarisu, kao bratu po oružju iz Prvoga svjetskog rata, oslobođen je i do kraja rata tiho živi u Beču. U poznoj životnoj dobi pomagao je Amerikancima u uspostavi zametaka vojske buduće Republike Austrije i njezine obavještajne službe, no umro je prije nego što je doživio njezino stjecanje neovisnosti. Djela: Kriegs- und Industrie Spionage; Meister der Spionage (Leipzig; Wien, 1935.). Literatura: MORITZ, LEIDINGER, JAGSCHITZ, Im Zentrum der Macht; PETHÖ, Agenten für den Doppeladler.

20 István Tisza (1861. - 1918.), mađarski političar, sin Kálmána Tisze. Doktorirao političke znanosti na Oxfordu, od 1910. na čelu Nacionalne stranke rada (Munkáspárt), ministar predsjednik 1903. - 1905. i 1913. - 1917. Zastupnik veleposjedničkoga dijela mađarskih vladajućih krugova, jedan od glavnih nositelja politike nacionalnoga pritiska na nemađarske narode $\mathrm{u}$ Ugarskoj. Radio je na tijesnom povezivanju Ugarske s Austrijom i Njemačkom. Sporazumom s HSK-om 1913. ukinuo komesarijat u Hrvatskoj i za bana postavio Ivana Skerlecza te povukao prijepornu Željezničku pragmatiku. Zbog dosljednoga pridržavanja i provedbe Austro-ugarske nagodbe u posljednjim godinama života Franje Josipa uživa njegovo osobno povjerenje, što ga kao ugarskoga predstavnika zbog složene strukture Monarhije čini najmoćnijom osobom nakon cara i kralja. Zbog Tiszinih protivljenja reformama, osobito izbornoj, Karlo I. (IV.) prisilio ga je da odstupi 1917., međutim zadržao je politički utjecaj u Ugarskoj. Potom je na vojnim dužnostima do odlaska na posebnu misiju na jugu Monarhije u rujnu 1918. godine. Ubijen u atentatu.

${ }^{21}$ Stjepan Sarkotić (1858. - 1938.), austrijski general, rođen u Sincu kod Otočca. Završio senjsku gimnaziju, školovanje nastavio na vojnoj školi u Sankt Pöltenu i Vojnoj akademiji u Beč- 
Po Rongeovu mišljenju, Tisza mu je zadao i „bočni udarac” pomalo ironično rekavši: „Dakle morao bi posebno obratiti pomnju na informacije koje potječu iz hrvatskih izvora”, aludirajući time između redaka na frankovačke veze s vojnim vrhom. ${ }^{22}$

Vezano uz odnos civilnih i vojnih vlasti važno je razumijevati da su civilne ulazile u sukob s vojnima zbog postupaka s politički sumnjivim osobama u raznim mjestima i na različitim položajima u Hrvatskoj.

U kolovozu 1914. zapovjednik XIII. zbora general Adolf Rhemen dostavio je Etapnom zapovjedništvu 5. armije dojavu o velikosrpskom pokretu u Bjelovaru koje je dovodilo u nepovoljan položaj vladina povjerenika dr. Teodora Bošnjaka. Etapno zapovjedništvo uputilo je 30. kolovoza 1914. ugarskom ministru predsjedniku Tiszi molbu da se u interesu sigurnosti vojske i države poduzmu izvidi i pretrage kojima bi se sanirala situacija u Bjelovaru. General Rhemen, kao zapovijedajući u Zagrebu, naznačio je da je Bošnjakovo ponašanje poznato u Hrvatskoj, pri čemu to nije smatrao potrebnim ni obrazložiti, te je predložio da se iz državno-političkih razloga razmotri njegov opoziv, o čemu je obaviješten i ban. ${ }^{23}$

Zbog odlaska Rhemena na bojište ban Skerlecz nastavlja korespondenciju $s$ generalom Eugenom Scheureom, zagrebačkim vojnim zapovjednikom, u pitanju vladina povjerenika u Bjelovaru dr. Bošnjaka 26. kolovoza 1914. godine:

kom Novom Mjestu. Od 1884. na različitim vojnim dužnostima u Češkoj i Bosni i Hercegovini. Kao perspektivan kadar, upućen je na školovanje u bečku Ratnu školu, a po njezinu završetku raspoređen je na službu u Glavni stožer na obavještajne poslove te putuje po Srbiji, Bugarskoj, Makedoniji i ući ruski jezik u Kazanju. Odlazi na dužnost načelnika stožera 7. pješačke divizije u Osijek, a potom u Prag i Pulu i ugarski Nagyszeben, što sve prate i promaknuća u više činove: 1907. promaknut u čin general-bojnika te preuzeo zapovjedništvo 5. pješačke brigade u Linzu, 1911. promaknut u podmaršala, 1912. zamjenjuje Svetozara Borojevića kao zapovjednik VI. kr. ugarskog domobranskog okruga (Hrvatsko-slavonsko domobranstvo) u Zagrebu. Početkom Prvoga svjetskog rata jedan od glavnih austrijskih zapovjednika na srbijanskom bojištu, 22. prosinca 1914. postao svjetovni poglavar Bosne i Hercegovine te zapovijedajući general vojnih snaga u Bosni, Hercegovini i Dalmaciji nadređen XV. sarajevskom i XVI. dubrovačkom zboru. Sudjelovao je u okupaciji Crne Gore i dobio titulu barun lovćenski. U proljeće 1915., stekavši dobar pregled situacije na jugu, ocijenio je srpsko pitanje opasnim za sigurnost Monarhije te zatražio da Cislajtanija i Translajtanija poduzmu jedinstvene protumjere. Vrhovno vojno zapovjedništvo o tome je obavijestilo i austrijsku i ugarsku vladu, od kojih je potonja reagirala s nevjericom. Godine 1916. proglašen je počasnim građaninom grada Zagreba. Od 1917. do kraja rata pokušavao je potaknuti reformu Monarhije na jugu i tako riješiti hrvatsko pitanje. Osoba od povjerenja Karla I. (IV.). Nakon rata otišao je u emigraciju u Austriju te s Ivanom Perčevićem i Stjepanom Duićem utemeljio Hrvatski komitet i vodio ga do 1929., kada ga zamjenjuje Ante Pavelić (odvjetnik). U bečkom Reichspostu objavljivao članke protiv Jugoslavije i Karađorđevića, zalažući se za samostalnu Hrvatsku, što su austrijske vlasti tolerirale, ali da se ne zamjere vlastima Kraljevine Srba, Hrvata i Slovenaca, nisu pružale nikakvu djelatnu potporu aktivnostima Hrvatskoga komiteta. Djela: Radićevo izdajstvo (Beč, 1925.) i Razmatranja o današnjem stanju hrvatskog naroda (Beč, 1925.) te „Die Hochverrats-Prozeß von Banja Luka”, Die Kriegsschuldfrage - berliner Monatshefte für internationale Aufklärung (Berlin) 7 (1929), br. 1: 30-47. Vidi i: HR-HDA-1773, Osobni fond generala Stjepana Sarkotića, Dnevnik, kut. 1-5 i ČUTURA, „Sarkotić - časnik, strateg i političar".

${ }^{22}$ RONGE, Kriegs- und Industrie Spionage, 171.

${ }^{23}$ HR-HDA-79-UOZV, SDDS, kut. 5702, bez broja spisa, dok. br. 57. 
„Vezano za dopis od 21. kolovoza 1914. (banov, [Präs.nr. 853]) koji je slijedilo i pismo od 22. kolovoza 1914. broj 171 res. u predmetu prokazivanja odnosa $\mathrm{u}$ bjelovarskom kotaru, podijelio bih s vama da me je vladin povjerenik dr. Bošnjak uljudno zamolio, da ga se s obzirom na slučaj s njegovim šurjakom Omčikusom razriješi s položaja vladina povjerenika za Bjelovar. Nakon toga ispitao sam $\mathrm{s}$ ugarskim ministrom predsjednikom mogućnost promjene na tom mjestu pod takvim okolnostima, koju držimo nužnim, pa bi spomenuti vladin povjerenik s tog položaja bio razriješen, a na njegovo mjesto bio bi postavljen ovdašnji odjelni savjetnik kazališnoga intendanta Vladimir von Treščec. Premda prijava u mnogim točkama, osobito glede dr. Bošnjaka, zvuči nevjerojatno, ja sam ju novom vladinu povjereniku predao na daljnje postupanje zbog spomenutoga rodbinskog odnosa dr. Bošnjaka." ${ }^{24}$

Tijekom saborske rasprave 30. lipnja 1914., dakle nakon ubojstva Franje Ferdinanda, nabrojeni su hrvatski političari koji su u bliskoj prošlosti putovali u Beograd (i Bitolu) ili dobili srbijanska odlikovanja, među njima i saborski zastupnici Koalicije Bogoslav Mažuranić, Milan Rojc, pa zagrebački gradonačelnik Janko Holjac i Hinko Hinković. ${ }^{25}$ Ovdje možemo reći da u mirno doba i uz dobre međudržavne odnose to i ne bi bilo neobično, no nakon promjene dinastije u Srbiji odnosi ipak više nisu bili tako dobri. Pri ocjenjivanju prihvatljivosti dodjele i prihvaćanja takvih odlikovanja situaciju su usložnjavale povremene težnje Austrije za poboljšanjem odnosa sa Srbijom, pa i privlačenje Srbije u austrijsku interesnu zonu. ${ }^{26}$

K tome je glede Holjca vlastima bila poznata okolnost bečke proslave 50 . godišnjice srpskoga akademskoga potpornog društva Zora na Vidovdan 1914.,

${ }^{24}$ HR-HDA-79-UOZV, SDDS, kut. 5689, spis 403/14, dok. br. 5669/Pr.-1914.

25 KRIZMAN, Hrvatska u Prvom svjetskom ratu, 74.

${ }^{26}$ Aehrenthal je dopuštao mogućnost mirnoga privlačenja Srbije u sastav Monarhije, pa je u tom cilju u svibnju 1908. službeni list njegova ministarstva Wiener Allgemeine Zeitung pozvao Srpsku samostalnu stranku da podrži aneksiju Bosne i Hercegovine kao prvi korak prema stvaranju Velike Srbije unutar Monarhije. Osvrt na taj članak pod nazivom "Austrijsko snubljenje” donijelo je Hrvatsko pravo (Zagreb), 7. 5. 1908. U tom se pozivu u romantičarskom tonu laskalo Srbima u Hrvatskoj da su na najvišem kulturnom stupnju od svih Srba, što imaju zahvaliti razvitku pod vlašću Habsburgovaca, zbog čega su predodređeni biti pionirima austrougarske politike u jugoistočnoj Europi. Nije isključeno da je i nadvojvoda Ferdinand tada bio blizak toj ideji s obzirom na to da ga je, prema Pavlu Rauchu, zanimalo širenje Monarhije preko Drine. Rauch naime smatra da je još prije početka, a i tijekom aneksijske krize (kao i Veleizdajničkoga procesa u Zagrebu) prijestolonasljednik bio naklonjen ideji da se Srbiju privuče u zonu utjecaja Monarhije, pa i više od toga, stoga je tada Ferdinand distanciran od bliskih mu pravaških (frankovačkih) krugova u Hrvatskoj, kao i od protusrpske kampanje, posljedično i od samoga Raucha, te nije prihvaćao ni ideju inače bliskog mu Conrada o preventivnom ratu protiv Srbije. Naime, Ferdinandova državnička politika, bar u tom razdoblju, protezala se i izvan granica Monarhije, želeći na jugoistoku mirnim putem proširiti utjecaj i na Srbiju i Rumunjsku razmišljajući čak i o njihovu pridruživanju Austrijskom Carstvu kao vazalnih država, slično odnosu Bavarske i Njemačke, iza čega su stajali austrijski gospodarski interesi, a Rauchova se zadržavala u okviru Monarhije. Tajne pregovore Beča i Srpske samostalne stranke kao dijela HSK-a iz banske Hrvatske 1907. potvrđuje S. Pribićević i navodi da su odbili ponude Beča. Vidi: RAUCH, Memoari bana Pavla Raucha, 111-112; S. PRIBIĆEVIĆ, Diktatura kralja Aleksandra, 162; KRIŠTO, Prešućena povijest, 260. 
dakle na dan Sarajevskoga atentata. Na popisu Počasnoga odbora nalazili su se uz visoke državne i vojne dužnosnike Srbije te Narodne odbrane i istaknuti članovi HSK-a, među kojima i zagrebački gradonačelnik Janko Holjac. Zora je bila jezgra jugoslavenskoga nacionalističkog pokreta, unutar kojega je od 1908. u Bosni i Hercegovini među tamošnjim Srbima nastalo tajno revolucionarno udruženje poznatije pod imenom Mlada Bosna, koje je postalo središnja organizacija mreže tajnih omladinskih udruženja Bosne i Hercegovine. Djelatnost Zore utjecala je i na radikalizaciju hrvatske napredne mladeži.

Afera sa Zorinim popisom dodatno je kompromitirala Holjca jer mu je u lipnju 1914. dodijeljeno srbijansko odličje Bijeli orao. K tome je Holjac bio član slobodnozidarske lože ${ }^{27}$ povezane sa srbijanskim slobodnozidarskim ložama, a dvojica njezinih članova - vojni časnici Vojislav Tankosić i Milan Ciganović - bili su suorganizatori terorističke organizacije $\mathrm{Crna} \mathrm{ruka}^{28} \mathrm{i}$ atentata na Ferdinanda. Zbog Zorina popisa Holjac je pozvan na političku odgovornost te je u Predsjedništvu Zemaljske vlade izjavio da se njegovo ime našlo na popisu bez njegova znanja. S tim je stvar završila. Međutim, u prosincu 1914. vojni zapovjednik predbacio je Holjcu da nije organizirao doličnu proslavu zauzeća Beograda te da, sumnjajući u njegovu lojalnost, očekuje njegov odstup. Holjac je zato zatražio zaštitu bana Skerlecza, koji je prijavio generala Scheurea Ministarstvu rata tvrdeći da je Scheure time prekoračio svoje ovlasti. ${ }^{29}$

Nadalje, u kolovozu 1914. pakrački Hrvati podnijeli su hrvatskoj vladi i Vojnom zapovjedništvu u Zagrebu prijavu protiv kotarskoga predstojnika u Pakracu Steve Runjanina, kojega su optužili da je kao Srbin štitio širenje velikosrpske propagande u tom kotaru. Budući da je u Runjaninovu obranu stao vladin povjerenik za Požešku županiju Dragan pl. Trnski, pakrački su Hrvati vojnim vlastima podnijeli prijavu i protiv Trnskoga. Vojne su vlasti od bana zatražile smjenu vladina povjerenika i kotarskoga predstojnika u Pakracu, čemu se ban usprotivio. ${ }^{30}$ Stevo Runjanin ipak je smijenjen, a novi kotarski predstojnik u Pakracu u studenom je javio banu da su se tvrdnje iznesene u prijavi pakračkih Hrvata protiv Runjanina pokazale istinitima.

Tijekom nastavka sukoba civilnih i vojnih vlasti u Požeškoj županiji zagrebački vojni zapovjednik general Scheure u tu je županiju bez znanja hrvatskoga bana poslao povjerenstvo koje je trebalo provjeriti istinitost prijave da se iz te županije nesmetano komunicira s neprijateljem. Rezultati te istrage trebali su kompromitirati vladina povjerenika Trnskoga i prisiliti bana Skerlecza da

${ }^{27}$ O masonima vidi: MUŽIĆ, Masonstvo u Hrvata; NENEZIĆ, Masoni u Jugoslaviji (17641980); ŠÖMEN, Amenkamen - slobodnozidarska čitanka; ŠÖMEN, Povijest slobodnog zidarstva u Hrvatskoj (I-III).

${ }_{28}$ O Crnoj ruci vidi: RONGE, Kriegs- und Industrie Spionage, 58-59, 63; DEDIJER, Sarajevo 1914 (I-II); S. PRIBIĆEVIĆ, Diktatura kralja Aleksandra; CLARK, The Sleepwalkers; MACKENZIE, Apis, čovjek koji je izazvao Prvi svjetski rat; VUCINICH, Serbia Between East and West; JOVANOVIĆ, Vlada Aleksandra Obrenovića; VASIĆ, Devetstotreća (majski prevrat); WEST, Black Lamb and Grey Falcon; PETHÖ, Agenten für den Doppeladler.

29 HR-HDA-78-PRZV, kut. 856, spis 9035/14.

${ }^{30}$ HR-HDA-78-PRZV, kut. 871, spis 5661/14 i spis 6528/14. 
ga smijeni. ${ }^{31}$ Međutim, kada se saznalo za postojanje te komisije, izbio je skandal zbog kojega je vladar u ožujku 1915. morao smijeniti kompromitiranoga Scheurea. Ovdje, po našem shvaćanju, treba pripomenuti da postupak vojnih vlasti nije iznenađivao. Naime, ban je na početku pakračke krize odbio smijeniti i Runjanina i Trnskoga. Tijekom događaja promijenio je mišljenje i pristao žrtvovati kotarskoga predstojnika, za koga je idući predstojnik dokazima potvrdio navode iznesene u predstavci pakračkih Hrvata. S obzirom na to da je ban zaštitio Trnskoga, bilo je očekivano da Skerlecz ne bi prihvatio osnivanje zajedničkoga povjerenstva koje bi rasvijetlilo ponašanje vladina povjerenika u pakračkoj krizi. Izbijanjem skandala i smjenom Scheurea civilne vlasti postigle su „pobjedu”, međutim s dalekosežne točke sigurnosnoga gledišta nismo dobili odgovor na pitanje je li i Trnski bio hotimice umiješan u nedopuštene aktivnosti ili ih je svojim zaštitničkim stavom moguće nehotice tolerirao. U svjetlu takvih okolnosti Skerleczova potpora Trnskome mogla je u konačnici rezultirati i banovom smjenom, pa i uvođenjem vojne uprave u Hrvatskoj, što nije odgovaralo ni Koaliciji ni ugarskom ministru predsjedniku Tiszi. Kako je izbio skandal, Scheure je smijenjen, vojna komisija prekinula je rad, a pitanje je li vladin povjerenik veliki župan Trnski bio sigurnosno problematičan ostalo je bez odgovora.

Zbog izostanka aktivnog uhodarstva ili pobuna u banskoj Hrvatskoj od 1914. do 1915. sigurnosna situacija bila je naizgled povoljna no ipak su bili česti slučajevi kaznenih djela uznemiravanja javnoga reda i mira i uvrede, što je bila pravna kvalifikacija za velikosrpsku propagandu, ponekad i talijanski iredentizam, zatim uvrede veličanstva i širenje lažnih vijesti. Teritorijalno je primjetno da su se slučajevi velikosrpske propagande najčešće javljali u Srijemu, zapadnoj Slavoniji, na Kordunu, Banovini i u Lici, pri čemu je prava erupcija političke nelojalnosti podanika Monarhiji zabilježena za vrijeme srbijanske vojne invazije istočnoga Srijema u rujnu 1914., zbog čega je protiv više stotina osoba pokrenut kazneni postupak zbog veleizdaje, i to u stjecaju s različitim oblicima ponašanja (poticanje na ubojstvo lojalnih građana ili zarobljenih austrougarskih vojnika, prikrivanje ubojstava nesrba, bijeg s neprijateljskom vojskom, pridruživanje i pomaganje neprijateljskoj vojsci na različite načine, svečani doček neprijateljske vojske, masovno pljačkanje državne ili privatne imovine i tome slično). ${ }^{32}$ Post festum, 19. prosinca 1915. vladin povjerenik za Srijemsku županiju Imbro Hideghéthy za velikosrpsku agitaciju prema pravoslavnom pučanstvu i njihove veze sa Srbijom označio je odgovornim Srpsku samostalnu stranku iz Zagreba kao dio HSK-a te vojvođansku srpsku Radikalnu stranku, koja je prije djelovala i u Srijemskim Karlovcima, jer su one određivale lokalnu politiku. ${ }^{33}$

\footnotetext{
${ }^{31}$ GABELICA, „Političke prilike u Banskoj Hrvatskoj na početku Prvoga svjetskog rata”, 183.

${ }^{32}$ HR-HDA-79-UOZV, SDDS, kut. 5699, spis 2254/15.

${ }^{33}$ HR-HDA-79-UOZV, SDDS, kut. 5696, spis 3760/15 (uloženo u spis 1793/15), dok. br. 14237.
} 
Prema Šurminu, da bi se doskočilo „unutrašnjem neprijatelju”, vojne vlasti u Hrvatskoj predlagale su raspuštanje hrvatskoga Sabora radi ukidanja imuniteta zastupnicima Koalicije koji su vodili protudržavnu djelatnost, zatim stavljanje tiska pod osobito strogu cenzuru, zabranu srpskoga imena i ćirilice u javnom životu Hrvatske te popunu činovničkih položaja lojalnim osobama. ${ }^{34}$ Na temelju tih izvješća AOK se više puta obratio i Franji Josipu I., obavještavajući ga da je vojska nezadovoljna stanjem u Hrvatskoj, gdje, po njihovu mišljenju, hrvatska vlada nije željela strogim mjerama spriječiti pokret srbofilskih čimbenika, „koji nesumnjivo naginju veleizdaji”, nego im je pogodovala. Zbog toga je AOK od vladara i zatražio uvođenje vojne uprave u banskoj Hrvatskoj.

U proljeće 1915. general Stjepan Sarkotić, vojni zapovjednik Dalmacije i Bosne i Hercegovine te zemaljski poglavar Bosne i Hercegovine, izrazio je AOK-u mišljenje da se u Monarhiji u vezi sa srpskim pitanjem mora postupiti jedinstveno. Ugarska vlada tada je još radi zaštite svojih interesa podržavala Srbe u banskoj Hrvatskoj, što nije bilo dopustivo sa stajališta sigurnosti. Istodobna upozorenja zagrebačkoga vojnog zapovjednika o potpori državnih struktura unutar banske vlasti velikosrpskoj propagandi, o nelojalnim pojedincima te odgovornim položajima u upravi zemlje na kojima su nesmetano bile pojedine nelojalne osobe odbacivale su kao previše pesimistična ili zloguka i banska vlast i zajednička Hrvatsko-ugarska vlada. Evidenzbureau je bio začuđen što hrvatski Sabor nije skinuo zastupnički imunitet Hinku Hinkoviću, koji je od početka rata živio u neutralnom ili neprijateljskom inozemstvu i koji je s Antom Trumbićem, Franom Supilom i ostalima osnovao Jugoslavenski odbor, a po njegovu premještaju u London objavio je manifest protudržavnoga sadržaja protiv Monarhije, propagirajući osnutak jugoslavenskoga kraljevstva u kojem će vladati „mir i red”.

Uz zaštitu istaknutijih nelojalnih osoba od kaznenoga progona u banskoj Hrvatskoj istodobno je vođeno više mučnih sudskih postupaka protiv malih ljudi - srpskih seljaka zbog velikosrpske propagande koju su oni do tada provodili nesmetano uz zaštitu ili blagonaklonost lokalnih vlasti. Stoga su, po mišljenju Rongea, u banskoj Hrvatskoj veleizdaja, uvreda veličanstva i zločinstvo remećenja javnoga reda (pravna formula za velikosrpsku propagandu) samo u malom broju slučajeva naišli na energičan odgovor civilnih vlasti te dodaje da u takvim okolnostima „Naravno da su kralju privrženi Hrvati osjećali ogorčenje i htjeli raskid svojih veza s Ugarskom, kao i s takvim velikosrpskim činovništvom [großserbischen Beamtentums]". ${ }^{35}$

\section{Preustroj sigurnosnoga sustava}

Prije samoga preustroja, ali povezano s njim, ban Skerlecz donio je 30 . srpnja 1915. Naredbu br. 7660 Pr. o promjeni poslovnoga djelovanja odsjeka

\footnotetext{
${ }^{34}$ ŠURMIN, Vojska i hrvatska politika 1915., 115-117.

${ }_{35}$ RONGE, Kriegs- und Industrie Spionage, 183.
} 
IV. Unutarnjega odjela i Predsjedničkoga ureda Kraljevske zemaljske vlade, kojom je IV. odsjek podijelio na dva odsjeka: Odsjek IV-A za redarstvene, vojničke i oružničke poslove i Odsjek IV-B za poslove pograničnih redarstvenih satništva.

Ban je Naredbom odredio da se iz poslovnoga djelovanja IV. odsjeka Unutarnjega odjela izluče i prebace u novi odsjek sljedeći poslovi: pogranično redarstvo (zakonski članak VIII. iz 1903. zajedničkoga Ugarsko-hrvatskoga državnog sabora o pograničnom redarstvu); rješavanje pravnih lijekova o putovničkom poslu (zakonski članak VI. iz 1903. zajedničkoga Ugarsko-hrvatskoga državnog sabora o putovničkom poslu); rješavanje pravnih lijekova o stanovanju inozemaca (zakonski članak V. iz 1903. zajedničkoga Ugarsko-hrvatskoga državnog sabora o stanovanju inozemaca na području zemalja krune Ugarske); nadzor nad redarstvenim oblastima glede predmeta spadajućih u djelokrug Odsjeka; davanje mišljenja Odsjeku IV-A o molbama za dozvolu sakupljanja prinosa u dobrotvorne ili ine svrhe; davanje mišljenja o osnivanju i raspustu svih društava koja spadaju pod ustanovu carskoga patenta od 1852 . godine; tiskovni poslovi; provođenje Zakona o pravu skupljati se (o pravu okupljanja). Nadalje je Naredbom bilo propisano da se iz poslovnoga djelovanja Predsjedničkoga ureda Kraljevske zemaljske vlade izlučuju te prelaze u novi odsjek: više državno redarstvo i tiskovno redarstvo, poimenično nadzor tiska i novina, dozvola za prodavanje periodičkih i inih tiskopisa (novina) te uredovanje glede oduzimanja pogodnosti poštanskoga otpremanja pojedinih tiskopisa koji pišu neprijateljski protiv države i zemlje. Ban je odredio naziv toga odsjeka: „IV.B odsjek za pogranična redarstvena satništva”, a dotadašnji IV. odsjek (redarstveni) promijenio je naziv u „IV.A odsjek za poslove redarstvene, te vojničke i oružničke”.

Ban je ujedno odredio da se njegovom naredbom od 17. lipnja 1914. br. 3320 Pr. izdana razdioba poslova Zemaljske vlade, Odjela za unutarnje poslove, imala u smislu naredbe od 30. srpnja 1915. ispraviti. ${ }^{36}$ Ta je naredba stupila na snagu 30. srpnja 1915. godine.

Nešto prije, 20. srpnja 1915., ban Skerlecz donio je Naredbu broj 13281915. s.d.d.s., ${ }^{37}$ kojom je odredio da se „Središnji ured za defensivno doglasnu službu" (ustrojen naredbom od 6. lipnja 1914. broj 86. res) priključuje od 15. kolovoza $1915 .{ }^{38}$ Odsjeku IV-B za pogranična redarstvena satništva. ${ }^{39}$ Ujedno

${ }^{36}$ HR-HDA-1363, bivši Arhiv Instituta za historiju radničkog pokreta, grupa XXI (Politička situacija), kut. 1 , inv. br. 5 .

37 HR-HDA-79-UOZV, SDDS, kut. 5694, spis 1328/15.

38 U spisu postoji i identična inačica potpisane Naredbe s jednom razlikom - njome je početak rada SDDS-a određen za 1. (pisano pisaćim strojem), a ne 15. (ispravljeno rukom) kolovoza 1915. godine. Može se vjerovati da je prvotni cilj bio da SDDS po preustroju zaista započne s radom 1. kolovoza, no kako je banskom naredbom Odsjek IV-B formalno bio osnovan 30 . srpnja, ali praktično je kao takav počeo raditi nakon 1. kolovoza, došlo je i do promjene datuma pripajanja SDDS-a Odsjeku IV-B na 15. kolovoza jer ne bi bilo izvedivo da se SDDS pripoji odsjeku kojega još nema.

39 U izvorniku: „satničtva”. 
je $s$ istim danom SDDS u pogledu vodstva, unutarnjega uređenja („uredbe”), nadzora i uporabe osoblja podredio upravitelju Odsjeka IV-B. Ponovo je odredio glavne urede (u izvorniku: „glavna mjesta”) Defenzivno doglasne službe:

1) Kraljevsko redarstveno povjereništvo ${ }^{40} \mathrm{u} Z$ Zagrebu za grad Zagreb, za opseg Zagrebačke, Varaždinske i Bjelovarsko-križevačke županije te za kraljevski slobodni grad Varaždin;

2) Kraljevsko redarstveno povjereništvo u Osijeku za grad Osijek te Virovitičku i Požešku županiju;

3) Kraljevsko pogranično redarstveno satništvo u Zemunu za gradove Zemun, Petrovaradin i Srijemske Karlovce te kotareve Zemun, Stara Pazova i Irig;

4) Kraljevsko pogranično redarstveno satništvo u Mitrovici (danas Srijemska Mitrovica) za grad i kotar Mitrovica te kotareve Ruma, Šid, Ilok, Županja, Vinkovci i Vukovar;

5) Kraljevsko pogranično redarstveno satništvo u Sušaku za gradove Bakar, Karlobag i Senj te Modruško-riječku i Ličko-krbavsku županiju.

Nadalje, Naredbom je bilo propisano da se ustrojavanjem Središnjega i glavnih ureda Defenzivno doglasne službe ne mijenja zakoniti djelokrug kotarskih oblasti, redarstvenih povjereništava i gradskih poglavarstava kao redarstvenih oblasti. Te su oblasti i dalje bile obvezne surađivati s Defenzivno doglasnom službom te ju obavijestiti brzojavno ili telefonski o svakoj osobi koja je zbog sumnje na uhodarstvo bila predana nadležnom sudu na daljnji postupak ili je zbog sumnje na uhodarstvo po političkim oblastima (teritorijalnim jedinicama vlasti - općinama, kotarevima, županijama i gradovima) bila uhićena, a potom zbog pomanjkanja dokaza puštena na slobodu, o svim sumnjivim uhodama koje nije bilo moguće uhititi i o svim slučajevima uhodarstva gdje je počinitelj bio nepoznat. Sve takve prijave trebale su sadržavati ime i prezime te osobni opis sumnjive osobe, a po mogućnosti prilagane su fotografije, otisci prstiju, rukopisi, podaci o kretanju i komunikaciji sumnjivih osoba te općenito sve što se moglo smatrati važnim.

Tako dugo dok Središnji ured ne bi odredio drukčije, teritorijalno nadležne političke oblasti bile su obvezne poduzeti sve potrebne mjere po vlastitom nahođenju i na vlastitu odgovornost. U važnim slučajevima Središnji ured mogao je uredovati po vlastitim činovnicima ili ta uredovanja prepustiti teritorijalno nadležnom glavnom uredu. Ako bi na terenu došlo do postupanja organa (činovnika) samoga Središnjeg ureda ili pak od Središnjega ureda opunomoćenih organa glavnih ureda, bilo je određeno da im je kotarska ili redarstvena oblast na čijem bi teritoriju središnji ili od njih opunomoćeni organi uredovali obvezna pomoći svim raspoloživim sredstvima. Kada glavni ured ne bi uredovao po nalogu Središnjega ureda nego na vlastiti poticaj ili na zahtjev vojne oblasti, bio je obvezan o tome odmah pismeno odnosno brzojavno ili telefonski izvijestiti Središnji ured.

\footnotetext{
${ }^{40}$ U izvorniku: „povjereničtvo”.
} 
Uredujući organi Središnjega i glavnih ureda bili su obvezni javiti se nadležnim kotarskim odnosno redarstvenim oblastima na čijem bi području uredovali te im se legitimirati. Isto tako pri teritorijalno nadležnim oblastima uredujući (u izvorniku: „eksponirani”) organi bili su obvezni zabilježiti svoje uredovanje u službenoj knjizi. Takva zabilježba mogla je izostati samo u slučaju nužnosti žurnoga postupanja, kada je postojala opasnost da se ugrozi uspjeh akcije (primjerice hvatanje uhode), no zabilježba se onda morala staviti naknadno, odmah po završetku akcije. Tu službenu knjigu Središnji ured bio je u obvezi dostaviti svim redarstvenim organima koji bi se našli u ulozi asistenta Defenzivno doglasne službe.

Središnji ured bio je obvezan sve važne događaje koji su se odnosili na Defenzivno doglasnu službu registrirati, sve zbog uhodarstva sumnjive ili osuđene osobe voditi u „očevidnosti” (preko „očevidnih listova” - danas bi to bili osobni dosjei) te općenito sabirati sve podatke koji su imali veze s radom Defenzivno doglasne službe. Takva zbirka podatka trebala je osim imena zbog uhodarstva sumnjivih ili osuđenih osoba, njihovih generalija i osobnoga opisa sadržavati i njihove fotografije, otiske prstiju, pseudonime, kontakte s drugim osobama sumnjivim zbog uhodarstva (špijunske agenturne mreže), osobite "knife" ${ }^{11} \mathrm{i}$ trikove uhoda i agenata. $U$ toj zbirci bilježeni su i uhodarski varalice - dakle oni koji su se predstavljali takvima, a to nisu bili.

Ujedno su Naredbom određeni načini prikupljanja podataka: u zemlji od domaćih vojnih mjesta (u ovom slučaju pojam „mjesto” označavao je vojnu ustrojstvenu jedinicu nadležnu za obavještajne poslove) i civilnih oblasti, od središnjih ureda Defenzivno doglasne službe u Beču, Budimpešti i Sarajevu, iz vlastitih neposrednih opažanja, bilo samoga Središnjeg ureda ili njegovih glavnih ureda, iz prijava povjerljivih osoba iz zemlje i inozemstva te na druge načine.

Bilo je propisano da će Središnji ured svim ovlaštenim tuzemnim mjestima i oblastima, kao i istovrsnim uredima u Beču, Budimpešti i Sarajevu na njihovu molbu ili iz vlastite pobude davati obavijesti koje bi se odnosile na rad Defenzivno doglasne službe, odnosno sudjelovati u razmjeni takvih podataka.

Središnji ured trebao je dobivene informacije prosljeđivati glavnim uredima odnosno kompetentnim kotarskim i redarstvenim oblastima na svojem području, i to izravno, a time ih i upozoriti da obrate pozornost na pojedine događaje ili osobe s njima u svezi, te im davati potrebne upute odnosno predlagati mjere koje je bilo potrebno poduzeti. Komunikacija između Defenzivno doglasne službe i oblasti (upravnih i drugih nadleštava) bila je redovito pismena. Iznimno se u žurnim slučajevima dopuštala šifrirana brzojavna ili telefonska komunikacija, ali bez povjerljivoga sadržaja. Podnesci Defenzivnoj doglasnoj službi trebali su se radi zaštite tajnosti podataka zatvarati u dvostruke omotnice. Vanjska je imala nositi adresu Kr. zemaljska vlada, IV-B odsjek za pogranična redarstvena satništva, a unutarnja Središnji ured za defenzivno

\footnotetext{
${ }^{41}$ Od njem. Kniff, „dosjetka, majstorija”.
} 
doglasnu službu, na vlastite ruke šefu ureda. Pisma su se ulagala u unutarnju omotnicu. Za brzojave se upotrebljava adresa Polmil ${ }^{42}$ Zagreb, a sadržaj brzojava šifrirao se po ključu 3.

Telefonske razgovore koji bi sadržavali podatke o poslu Defenzivno doglasne službe trebali su se izbjegavati, ali ako bi do njih došlo, njihov sadržaj imao se naknadno i pismeno priopćiti. Svi podaci vezani za rad Defenzivno doglasne službe, kao i pomagala, spisi i ini službeni podnesci koji su se odnosili na njih imali su strogo povjerljiv značaj te su se morali držati odvojeno od ostalih spisa i akata, neovisno o tome koja bi ih oblast vodila, te biti pohranjeni pod ključem. Stoga se izboru osoblja kojemu bi bilo povjereno rukovanje tim povjerljivim spisima imala posvetiti osobita pozornost.

Dužnost Središnjega ureda bila je nadziranje rada Defenzivno doglasne službe u svim upravnim područjima u banskoj Hrvatskoj, kontroliranje rada svih upravnih oblasti slanjem vlastitih djelatnika, upozoravanje predstojnika nadležne oblasti na uočene manjkavosti u njegovu području te određivanje mjera za otklanjanje nedostataka.

Naredbom je bila određena i obveza čestih službenih putovanja po pograničnim područjima za djelatnike Središnjega ureda da bi se na licu mjesta mogli osvjedočiti funkcionira li pravilno aparat ustrojen za obranu od uhodarstva, kao i da predstojnike oblasti kojima je na određenom području bilo povjereno upravljanje Defenzivno doglasnom službom upozoravaju na opažene manjkavosti i daju odredbe za njihovo odstranjivanje. Osobito se „kroz česta putovanja po pograničnim područjima imao središnji ured osvjedočiti da li tamo za obranu protiv uhodarstva ustrojeni aparat točno funkcionira”.

Nadalje, ban je odredio da se Središnji ured u Zagrebu i glavni uredi imaju sa drugim središnjim i glavnim uredima u Monarhiji, kao i vojnim oblastima, dopisivati na njemačkom jeziku.

Određeno je i da se dopisi odnosno molbe središnjih ureda u Beču, Budimpešti i Sarajevu i njihovih glavnih ureda te vojnih oblasti, uključujući i oružništvo - jer se i ono u žurnim slučajevima moglo neposredno obratiti glavnim uredima Defenzivno doglasne službe u Zagrebu, Osijeku, Zemunu, Mitrovici i Sušaku - imaju poštom u ovjerovljenom prijepisu slati središtu u Zagreb, a isto tako imalo se o rezultatima („posljedku”) nakon dovršenoga postupka izvijestiti. S Glavnim stožerom (Evidenzbureauom) izravno je mogao komunicirati jedino Središnji ured, iznimno u žurnim slučajevima i glavni uredi, ali su tada trebali ovjereni prijepis zamolnice Glavnom stožeru odmah poslati na znanje Središnjem uredu.

Posebna je dužnost Središnjega ureda bila nadziranje takozvane ambulantne željezničke nadzorne službe - nadziranje željezničkih putnika, koje je trebalo redovito obavljati s vlastitim organima. U osobitim slučajevima mogao je Središnji ured željezničke nadzorne ovlasti prenijeti i na glavni ured.

${ }^{42}$ Polmil je kratica od njem. politischemilitär, „političko-vojni”. 
Redarstveni organi Središnjega i glavnih ureda angažirani u ambulantnoj željezničkoj nadzornoj službi trebali su zaustaviti dvojbene putnike te ih predati na daljnji postupak najbližoj kotarskoj ili redarstvenoj oblasti uz prijavu i potvrdu u službenoj knjizi. Ujedno su glavni uredi imali obvezu o takvu postupku podnijeti izvješće Središnjem uredu.

Skerlecz je bio odredio i da se radi što bržega obavješćivanja dotičnih oblasti imao izdavati uhodarski list pod nazivom Vijestnik. U njemu su se trebale objavljivati sve potrage za sumnjivim uhodama, kao i njihove obustave, zatim upozorenja na uhodarske varalice i nepouzdane doušnike (konfidente) te druge obavijesti u svezi s Defenzivno doglasnom službom. Urednički posao trebao je obavljati Središnji ured. Ako bi glavni ured ili koja druga oblast u dogovoru s Defenzivno doglasnom službom (Središnjim uredom) željeli u uhodarski list uvrstiti kakvu vijest, morali su za objavu zamoliti Središnji ured.

Središnji i glavni uredi imali su u poslovima Defenzivno doglasne službe „u najvećem skladu općiti sa vojnim oblastima”.

Za glavne urede bilo je određeno da neće voditi nikakve vlastite „očevidnosti” (evidencije) jer je za to bio zadužen Središnji ured, ali ih je bilo potrebno obavijestiti o svakom slučaju uhodarstva. Tom naredbom stavljena je izvan snage naredba bana od 6. lipnja 1914. broj 86 res. $^{43}$

Iz same banske naredbe od 20. srpnja 1915. ne saznajemo ništa o mogućim razlozima preustroja SDDS-a te godine, no kao mogući uzrok i/ili povod preustroja pored navedenog možemo skrenuti pozornost na nekoliko dokumentiranih organizacijskih okolnosti i funkcionalnih potreba.

Reformom unutar ugarske vlade 20. srpnja 1915. u okviru V. redarstvenog odjela Ministarstva unutarnjih poslova osnovan je Pogranično-redarstveni odsjek, u kojem je skriven ugarski središnji ured za defenzivno doglasnu službu pod nazivom Obrambena doglasna centrala (VHK). Pogranično-redarstveni odsjek postao je nadređen svim pograničnim redarstvenim satništvima u Ugarskoj u njihovim redovnim zadacima, a ona su bila obvezna pomagati VHK-u u borbi protiv uhodarstva. Pomoć VHK-u u Budimpešti pružalo je Nadsatništvo državnoga redarstva glavnoga grada Budimpešte. Za financiranje VHK-a određen je proračun pograničnoga redarstva. Ugarski ministar unutarnjih poslova obavijestio je 15. kolovoza 1915. o tome Zemaljsku vladu u Zagrebu, a to joj je već prije bilo najavljeno preko vojnih krugova. ${ }^{44}$

Činjenica je da je Žiga Maravić od početka djelovao s visokim stupnjem samostalnosti u odnosu na bana Skerlecza jer se dopisivanje među svim središnjim uredima Defenzivno doglasne službe, uključujući i hrvatski, kao is Evidenzbureauom, odvijalo mimo bana. No takav način rada bio je definiran na konferenciji u Ministarstvu rata u Beču 1914., pa Skerlecz nije ni mogao prigovarati, bar ne otvoreno. Pravi kamen smutnje zapravo je bilo dopisivanje Glavnoga ureda vojne obavještajne službe u Zagrebu (njem. Nachrichtabteilung), pa

\footnotetext{
${ }^{43}$ HR-HDA-79-UOZV, SDDS, kut. 5694, spis 1328/15.

${ }^{44}$ HR-HDA-79-UOZV, SDDS, kut. 5687, spis 1746/15 (uloženo u spis 9/14), dok. br. 2587.
} 
i samoga Zapovjedništva XIII. zbora (njem. Generalstabschef) i zagrebačkoga vojnog zapovjednika (njem. Militärkommandant) izravno s SDDS-om u Zagrebu, koje je bilo osobito intenzivno, ako ne na dnevnoj, onda na tjednoj bazi. To je u Skerlecza moglo stvoriti dojam da su zagrebački vojni zapovjednik general Scheure, kao i prije Rhemen, razvili preblizak kontakt s upraviteljem SDDS-a Maravićem i da je Maravić zapravo pod prevelikim utjecajem Scheurea, a time i vojnih krugova.

Čini se da se tijekom 1915. Skerlecz opetovano zbog toga žalio i samome Tiszi. Ugarski ministar predsjednik uspio je postići da se Scheurea u Zagrebu zamijeni novim vojnim zapovjednikom, a kao izlika je vjerojatno iskorištena afera Runjanin (premda su se vukli i repovi afera Holjac, pa i Bošnjak), a Skerlecz usto provodi reformu Defenzivno doglasne službe, no ipak u koordinaciji s Evidenzbureauom. Nominalno je povod bila želja da se Defenzivno doglasna služba u banskoj Hrvatskoj ustroji na isti način kao u Ugarskoj s obzirom na to da je banska Hrvatska pripadala Kruni sv. Stjepana, bez obzira na visoki stupanj autonomije u unutarnjim poslovima. Obrambena doglasna centrala (VHK) kao središnji ured Defenzivno doglasne službe Ugarske nije djelovala kao samostalan ured pri ugarskoj vladi u Budimpešti, što je bio slučaj sa zagrebačkim SDDS-om u odnosu prema vladi banske Hrvatske, nego u okviru ugarskoga Ministarstva unutarnjih poslova (mađ. Magyar királyi Belügyministerium) kao poseban V. redarstveni glavni odjel (mađ. V. Rendöri föosztálya látja), koji je bio nadređen pograničnim redarstvenim satništvima. U srpnju 1915. dolazi do promjena time što su u okviru V. redarstvenoga glavnog odjela osnovani odsjeci i VHK je skriven pod Odsjekom za pogranična redarstvena satništva (mađ. Határrendörségi alosztályának). I sama vojska upozorila je Maravića da relativno slabiji rezultati SDDS-a u Hrvatskoj u poredbi s Bečom, Sarajevom i Budimpeštom mogu imati veze s nepostojanjem vlastitih podređenih organa, pa je isti koncept po uzoru na Ugarsku primijenjen 1915. i u banskoj Hrvatskoj, pri čemu je i dalje za svoj rad SDDS u Zagrebu (sada formalno pod nazivom Odsjek IV-B) u svim poslovima uhodarstva ostao izravno podređen Evidenzbureauu. Stoga je pitanje je li težnja da se ustroj Defenzivno doglasne službe, kao i poboljšanje rada, uredi po ugarskom modelu bila zapravo i uzrok preustroja ili je uzrokom bio spomenuti konflikt civilnih i vojnih vlasti, koji se onda prelamao i u borbi između Austrije i Ugarske za utjecaj nad radom SDDS-a u Zagrebu. Ne možemo zanemariti ni mogućnost da su takav razvoj događaja priželjkivali i određeni krugovi u okviru Koalicije jer bi provedbom reforme lakše mogli doći do povjerljivih informacija o radu SDDS-a, naravno ne iz časnih namjera.

Jedan od razloga preustroja mogao se očitavati i u želji da se rad SDDS-a što više prikrije. On je trebao biti tajan i što većem broju činovnika koji su radili u različitim vladinim uredima, županijskim i kotarskim nadleštvima i drugim institucijama, poput pošte. Sam SDDS u cijeloj Austro-Ugarskoj bio je vrlo tajna organizacija i jedino je njegov ured u Zagrebu djelovao pod tim nazivom. Svi ostali središnji uredi u Monarhiji djelovali su prikriveno pod 
drugim nazivima i uklopljeni su u sastav neke već postojeće oblasti: kao Policijska direkcija (Redarstveno ravnateljstvo, njem. Polizeidirektion in Wien) u Beču, Obrambena doglasna centrala u Budimpešti, prikriveno kao Odsjek za pogranična redarstvena satništva Ministarstva unutarnjih poslova, te u Bosni i Hercegovini kao samo Predsjedništvo Zemaljske vlade Bosne i Hercegovine (njem. Präsidium der Landesregierung für Bosnien und die Hercegovina).

Koliko je tajnost rada bila važna vidljivo je primjerice iz upute ugarskoga ministra financija zagrebačkom financijalnom ravnatelju da po dogovoru s mjesnim vojnim vlastima na području Hrvatske i Slavonije informira djelujuće podređene mu financijalne ravnatelje u shodnoj povjerljivoj formi o osnutku, zadaći i djelovanju i pisarni SDDS-a te da podređeno carinsko i osoblje financijalne straže uputi kako se već pokaže potrebnim, pri čemu: „Podredjenom osoblju ne imade se priopćiti svrha traženih podataka, ni to da postoji doglasna postaja [(SDDS-a], već valja to osoblje uputiti glede toga, da imena sumnjivih osoba, za koje je doznalo, prijavi uvijek svom predpostavljenom financ. ravnatelju - uz opis razloga protiv istima nastale sumnje - imajući na umu primjerenu opreznost." Ministar je potom odredio financijalnom ravnatelju u Zagrebu da svi njegovi podređeni financijalni ravnatelji izvješća za koja im se čini da su doista temeljita i važna priopće zagrebačkoj doglasnoj postaji, „obdržavajući” tražene zahtjeve povjerljivosti, te da o tako danim ministrovim odredbama obavijesti bana. ${ }^{45}$

U svjetlu očekivanoga preustroja SDDS-a u Hrvatskoj valjalo bi sagledati i promemoriju njegova upravitelja Maravića banu Skerleczu od 10. srpnja 1915., u kojoj se poziva na svoj odgovor AOK-u (spis broj 518 od 22. svibnja 1915.) te izraženu spremnost Evidenzbureaua, AOK-a, kao i na osobna objašnjenja Rongea Maraviću. Zanimljivo je da je Maravić promemoriju Skerleczu napisao na njemačkom.

U promemoriji se kaže da vezano za potrebu preustroja Središnji ured Zagreb nema vlastitih podređenih izvršnih organa, pa je stoga uspjeh njegova djelovanja bio manji od uspjeha koje su postizali središnji uredi Beč, Budimpešta i Sarajevo. No, da je rad središnjih ureda u svakom slučaju bio znatan bilo je vidljivo i iz proračunskih troškova koje su primjerice Beč i Budimpešta izdvajali za izvršne organe (operativce). Prema Maraviću, Ronge je spomenuo da zagrebački središnji ured nije imao vlastitih podređenih izvršnih organa koji bi bili financirani iz njihova proračuna, no kako su se njegove kvalitete ogledale u tome što se na vrhu svakoga od njegovih glavnih ureda ${ }^{46}$ nalazio povjerljivi činovnik koji je dodjeljivao zadatke, koji su se pak provodili na najbrži i najtočniji način, tako je i uspjeh Središnjega ureda Zagreb, osobito kad ostali središnji uredi iz različitih razloga nisu mogli istodobno djelovati, trebalo vrednovati, uzimajući u obzir njegove vlastite raspoložive resurse.

\footnotetext{
${ }^{45}$ HR-HDA-79-UOZV, SDDS, kut. 5695, spis 1504/15, dok. br. 53.

${ }^{46}$ Redarstvena povjereništva Zagreb i Osijek te pogranična redarstvena satništva Zemun, Mitrovica i Sušak.
} 
Izaslanik AOK-a Ronge slagao se s tim da Maravić izrazi banu stav vojnih vlasti da bi Središnji ured banske Hrvatske trebao dobiti vlastite izvršne organe. Pritom bi Zemaljska vlada za njegov rad trebala osigurati godišnje najmanje 50.000 kruna radi angažiranja potrebnog broja redarstvenih agenata i doušnika, koje bi kontrolirali državni činovnici raspoređeni na mjesta voditelja glavnih ureda. Ronge je povjerio Maraviću da je AOK namjeravao i izravno kontaktirati s banom u vezi s tim.

Podrobnija daljnja saznanja iskazana banu Maravić je saznao u središnjim uredima u Beču i Budimpešti. Tako je SDDS u Beču djelovao kao državnopolicijska referada pri Redarstvenom ravnateljstvu i izravno je bio podređen ravnatelju bečke policije Edmundu Gayeru. Sam bečki središnji ured imao je vlastite podređene izvršne organe, pa su pored voditelja djelovala još četiri činovnika, tri manipulativna činovnika, 40 detektiva i 15 konfidenata. Činovnici su bili podijeljeni u platne razrede od VII. do X. klase, a manipulativni činovnici od IX. do XI. klase. Detektivi su pored godišnje plaće dobivali dodatak od oko 2.000 kruna, što nije uključivalo putne troškove, a konfidentima se godišnje isplaćivalo od 2.400 do 4.800 kruna. Za sve svrhe Defenzivno doglasne službe Redarstveno ravnateljstvo u Beču raspolagalo je godišnjim proračunom od 232.000 kruna, s dodatnih 33.000 kruna za putne troškove, pri čemu su svi agenti imali besplatan prijevoz željeznicom. Zamjenik voditelja središnjega ureda bio je u rangu činovnika VII. klase. Voditelj bečkoga SDDS-a svakih osam dana brifirao je ministra unutarnjih poslova Cislajtanije Karla Heinolda o važnijim sigurnosnim događajima protekloga tjedna.

Središnji ured u Budimpešti djelovao je kao Odsjek za pogranična redarstvena satništva u ugarskom Ministarstvu unutarnjih poslova i imao vlastite izvršne organe, i to 56 redarstvenih agenata te doušnika po potrebi. Redarstveni agenti bili su XI. platnog razreda. Pored plaće isplaćivao im se godišnji dodatak od 1.800 do 2.400 kruna. Doušnici su dobivali nagradu ovisno o svojem uspjehu. Za potrebe rada budimpeštanski SDDS imao je na raspolaganju godišnji proračun od 200.000 kruna, a za putne troškove još 160.000 kruna. Izvješća o radu SDDS-a ugarskom ministru unutarnjih poslova Jánosu Sándo$\mathrm{ru}^{47}$ podnosio je voditelj Odsjeka za pogranična redarstvena satništva Gustav Ilosvay kao istodobni šef ugarskoga SDDS-a. ${ }^{48}$

S obzirom na raspoloživo ljudstvo i financijska sredstva nije čudio veći uspjeh u radu središnjih ureda u Beču i Budimpešti u odnosu na zagrebački,

${ }^{47}$ János Sándor (1860. - 1922.), ugarski političar, ministar unutarnjih poslova 1913. - 1917., Tiszin šogor.

${ }^{48}$ Ovdje moramo pripomenuti da Tisza nije vjerovao u veličinu obavještajne opasnosti. Smatrao je da vojna obavještajna služba goni „utvare”, što je, po njegovu mišljenju, poprimalo razmjere histerije. Stoga nije čudilo što su glavni uredi civilne defenzivno doglasne službe u Ugarskoj podređeni VHK-u Temišvar i Hermannstadt (danas Sibiu, Rumunjska) bili uspostavljeni tek godinu dana nakon izbijanja rata, u srpnju 1915., no bez ikakvih daljnjih instrukcija i s nedovoljno novca jer je Tisza bio uvjeren da je budimpeštansko državno redarstvo (Nadsatništvo državnoga redarstva stolnoga glavnoga grada) odlično u defenzivno doglasnim poslovima i da nema potrebe da se time bave i lokalne vlasti. RONGE, Kriegs- und Industrie Spionage, 192. 
stoga je Maravić podnio banu prijedlog da se SDDS Zagreb, koji je predstavljao državnopolicijsku referadu pri Predsjedništvu Zemaljske vlade, preuredi tako da bude samostalni odjel pod Predsjedništvom Zemaljske vlade. U tom odjelu kreirali bi se i predsjednički akti državnoga redarstva, koje je dotad moralo pripremati samo Predsjedništvo.

Voditelju Središnjega ureda u Zagrebu morala bi se za vođenje poslova dodijeliti tri činovnika (njem. Konzeptsbeamten), pri čemu bi jedan bio određen i za zamjenika voditelja u rangu VII. platnog razreda. S obzirom na veliki posao na vođenju „očevidnosti” u SDDS-u bilo je nužno osigurati i dva manipulativna činovnika, a pri kreiranju novoga odjela bila bi potrebna još dva. Središnji ured imao bi i vlastitu egzekutivu, kao i potrebnu kontrolu nad glavnim uredima, za što bi mu nužno bilo staviti na raspolaganje bar deset detektiva i deset doušnika. Detektivi bi morali biti zaposleni pri SDDS-u, a doušnici bi se angažirali preko glavnih ureda, kako se primjerice radilo u Ugarskoj.

Detektivi bi bili raspoređeni u XI. platni razred, a doušnici plaćeni po učinku. Maravić je iznio i prijedlog troškova za namještenje deset redarstvenih agenata u XI. platnom razredu, pri čemu bi za šest agenata s dodatkom od 1.810 kruna i za četiri s dodatkom od 2.410 kruna godišnje trebalo 20.500 kruna. Za deset konfidenata, koje bi se plaćalo oko 200 kruna mjesečno, trebalo bi godišnje 24.000 kruna, a za putne troškove i istraživanja još 10.000 kruna, što bi sve skupa godišnje iznosilo 54.500 kruna. Pored toga trebalo bi ishoditi besplatne karte za vlak za redarstvene agente SDDS-a. Maravić je zamolio bana da taj prijedlog uzme u razmatranje s najvećom pomnjom. Na promemoriji koju je Maravić napisao vidljivo je da je ban vlastoručno podcrtao ukupno tražen iznos od 54.500 kruna i to parafirao, što je, smatramo, značilo i odobrio prijedlog reforme SDDS-a u banskoj Hrvatskoj, kao i financijska sredstva. ${ }^{49}$ Nakon toga zaista su slijedile banska naredba od 30. srpnja 1915. (o diobi IV. odsjeka na odsjeke IV-A i IV-B) i banska naredba od 20. srpnja 1915. (o priključenju SDDS-a Odsjeku IV-B).

Bilo kako bilo, moramo istaknuti da je prema sadržaju spisa vidljivo da je po provedenom preustroju u okviru Odsjeka IV-B nastavila i po ljudstvu i po funkcijama djelovati Središnja defenzivno doglasna služba, ako već ne i po nazivu. Naime, svi dopisi koji se odašilju (uz pokoju iznimku) sve do kraja rata adresirani su na Središnju defenzivno doglasnu službu, u Odsjeku IV-B po njihovu zaprimanju svi dopisi urudžbirani su u poseban urudžbeni zapisnik pod oznakom s.d.d.s., a izlazne dokumente iz tematike SDDS-a Maravić je ovjeravao pečatom na kojem je pisalo Zemaljska Vlada - Središnja defenzivno doglasna služba. Inače, taj se pečat počeo koristiti tek u kolovozu 1915., dakle nakon preustroja! Dana 1. rujna 1915. pojavio se prvi put u upotrebi u spisima pečat SDDS-a. Bio je okrugao, promjera $32 \mathrm{~mm}$ s natpisom kr.Hrv.Slav.Dalm. zemaljska vlada, odio za unutarnje poslove SDDS, a u sredini pečata nalazio se

${ }^{49}$ HR-HDA-79-UOZV, SDDS, 5702, bez broja. Zapravo su novčana sredstva za rad SDDS-a bila osigurana u redovnom proračunu pograničnoga redarstvenog satništva, a dodatna sredstva pokrivana su vojnim dotacijama. 
grb Trojedne Kraljevine s krunom sv. Stjepana. ${ }^{50}$ Do tada je za ovjeru dokumenata SDDS koristio pečat Redarstvenoga odsjeka, bez natpisa SDDS, a prije je Maravić dokumente SDDS-a ovjeravao pečatom Redarstvenoga odsjeka. U skladu s tim i Hrvatski državni arhiv arhivsko gradivo SDDS-a vodi posebno u odnosu na arhivsku građu Odsjeka IV-B za pogranična redarstvena satništva pod oznakom UOZV-SDDS. ${ }^{51}$

Maravić je, naravno, i dalje bio istodobno i upravitelj Odsjeka IV-B za redarstvena pogranična satništva, koji je (pored poslova SDDS-a) imao i vlastiti djelokrug, i to u tadašnjim klasičnim državnopolicijskim poslovima: pograničnom redarstvu, rješavanju pravnih lijekova o putovničkom poslu, rješavanju pravnih lijekova o stanovanju inozemaca, nadzoru nad redarstvenim oblastima glede predmeta spadajućih u djelokrug Odsjeka, davanju mišljenja Odsjeku IV-A o molbama za dozvolu sakupljanja prinosa u dobrotvorne ili ine svrhe, davanju mišljenja o osnivanju i raspustu svih društava koja su spadala pod ustanovu carskoga patenta od 1852. godine, tiskovnim poslovima te provođenju Zakona o pravu skupljati se, zatim višega državnog redarstva i tiskovnoga redarstva, poimenično nadzora tiska i novina, dozvola za prodavanje periodičkih i inih tiskopisa (novina) te uredovanja glede oduzimanja pogodnosti poštanskoga otpremanja pojedinih tiskopisa koji su pisali neprijateljski protiv države i zemlje.

S obzirom na to da smo opisanim ustanovili da je SDDS bez obzira na preustroj zadržao potpunu funkcionalnu autonomiju u poslovima uhodarstva, i to do kraja rata, sve su njegove aktivnosti i dalje bile vođene pod nazivom SDDS, a ne Odsjek IV-B, jer se uostalom u korespondenciji unutar zatvorene omotnice pošta i dalje adresirala na SDDS.

Središnja defenzivno doglasna služba izdala je 15. listopada 1915. naredbu vezanu za pospješivanje izvidnih postupaka svim vladinim povjerenicima, redarstvenim povjereništvima, pograničnim redarstvenim satništvima i njihovim ispostavama, u skladu s uputom zajedničkoga ministra rata Krobatina ${ }^{52}$ iz

50 HR-HDA-79-UOZV, SDDS, kut. 5695, spis 1688/15, brzojav Landespräsidiumu Salzburg, sadržaj ispušten. Fond 79 u Hrvatskom državnom arhivu sadržava tisuće dokumenata zaprimljenih ili ovjerenih na taj način.

${ }^{51}$ Arhivsko gradivo Odsjeka IV-B predstavila je: STANIŠIĆ, „Odsjek IV-B res. za pogranična redarstvena satništva", 181-206.

${ }^{52}$ Alexander Krobatin (1849. - 1933.), austrougarski vojni časnik. Od 1865. student Topničke akademije, od 1869. na nižim časničkim dužnostima u vojnim postrojbama, a 1877. postaje predavač na Tehničkoj vojnoj akademiji u Beču. Godine 1889. promaknut u čin bojnika, 1890. postao ravnateljem Topničke kadetske škole. Godine 1895. promaknut u čin pukovnika i postao zapovjednikom 1. topničke pukovnije. Na dužnost u Ministarstvu rata raspoređen 1896., 1900. promaknut u general-bojnika, 1905. postaje podmaršal, 1910. general topništva, a 1912. ministar rata. Pokušava modernizirati austrougarsku vojsku, uvodi nova oružja, strojnice, topove i bacače plamena. Po odlasku njemu bliska generala Conrada s mjesta načelnika Glavnoga stožera zamolio je vladara imenovanje na dužnost na ratištu, čemu je udovoljeno. U travnju 1917. postao je zapovjednik 10. armije na talijanskom bojištu i sudjelovao u uspješnoj ofenzivi kod Kobarida, zahvaljujući čemu je promaknut u čin feldmaršala. U proljeće 1918. neuspješan u bitci kod Piave, a krajem listopada 1918. kao zapovjednik grupe armija doživljava poraz od Talijana u bitci kod mjesta Vittorio Veneto, u uvjetima općega rasula Austro-Ugarske. Po završetku rata 
Beča od 3. listopada 1915., br. 5397. Njome je bilo određeno da se u slučajevima u kojima je postojala sumnja o uhodarstvu uperenom protiv Austro-Ugarske obavezno poduzme kućna i osobna premetačina te pretraga spisa sumnjive osobe. Takvim uredovanjem dobivala su se ona dokazna sredstva - corpora delict $i$ - koja su često bila jedinom podlogom za uspješnu provedbu sudbenoga postupka. Stoga su sve navedene institucije bile obvezne u tim stvarima, čim bi došle u priliku u njima uredovati, postupati s najvećom brzinom te najvećom pomnjom i točnošću. Pri takvim uredovanjima bilo je određeno da obližnje „sigurnosne vlasti” (SDDS) smjesta pošalju iskusnoga izaslanika i zatraže asistenciju vojnoga vještaka od najbližega mjesnoga vojnog zapovjedništva odnosno najbližega vojnoga postajnog zapovjedništva. Maravić je napomenuo: „Osvrtom na važnost predmeta imade se ova naredba skroz povjerljivo u cijelosti strogo provađati." Ujedno je u naredbi naznačeno da je Zemaljska vlada, Odjel za pravosuđe, 11. listopada 1915. izdala okružnicu br. 7 res., kojom su sudske oblasti (sudbeni stolovi, državna odvjetništva, kotarski sudovi i njihove ispostave) bile upućene da u takvu uredovanju, a u stvarima koje su već došle pod nadležnost suda, smjesta pozovu i jednoga iskusnog izaslanika obližnje sigurnosne vlasti. ${ }^{53}$

Ipak je na području banske Hrvatske postojalo po sadržaju nepokriveno područje rada o kojem SDDS nije imao saznanja. Od početka rata (pa i prije) sve do sredine 1915. zapravo nije bilo suradnje između Financijalnoga ravnateljstva koje je djelovalo na području banske Hrvatske i Zemaljske vlade, pa time ni sa SDDS-om. Razlog je bio taj što je Financijalno ravnateljstvo za svoj rad, u skladu s Hrvatsko-ugarskom nagodbom i diobom poslova, odgovaralo zajedničkoj Hrvatsko-ugarskoj vladi u Budimpešti, pa je svoja izvješća koja su imala i malo veze s uhodarstvom slalo Ministarstvu financija odnosno VHK-u u Budimpeštu. Vojska je bila stajališta da je takvo što funkcionalno neprihvatljivo jer uslijed toga jurisdikcijskoga pitanja civilne vlasti u Hrvatskoj nisu znale za registrirane krijumčare robe koji su s teritorija Hrvatske prelazili u strane države, a takvi kanali mogli su poslužiti i za obavještajne poslove, stoga hrvatske vlasti nisu ni mogle primijeniti protumjere. Zahvaljujući vojnom angažmanu uspostavljena je suradnja u razmjeni podataka između Financijalnoga ravnateljstva i SDDS-a, premda je Ravnateljstvo nastavilo kopiju izvješća slati Budimpešti. Realizacija toga vojnog zahtjeva radi poboljšanja sigurnosti vodila je bansku Hrvatsku korak bliže k integraciji funkcija vlasti Zemaljske vlade na njezinu području i proširenju autonomije.

U tom se smislu Ugarsko-hrvatsko-slavonsko-dalmatinsko financijalno ravnateljstvo u Zagrebu obratilo banu 5. kolovoza 1915. s naznakom da ih je ugarski ministar financija János Teleszky, kojega je na to uputilo ugarsko Ministarstvo unutarnjih poslova, na poticaj zajedničkoga Ministarstva rata obavijestio o uspostavi „obrambene doglasne postaje” u Zagrebu (na hrvatskom

umirovljen, postao počasni doktor bečkoga Tehničkog sveučilišta i nastavio se baviti dobrotvornim radom.

${ }^{53}$ HR-HDA-79-UOZV, SDDS, kut. 5697, spis 2310/15 (uloženo u spis 2221/15). 
SDDS-a; „obrambena doglasna postaja/centrala” zapravo je doslovan prijevod naziva mađarskoga VHK-a), kojoj je zadatak bio da u prvom redu neprestano drži u „očevidnosti” sve osobe sumnjive zbog uhodarstva. Nadalje, ban je telefonski priopćio financijalnom ravnatelju Josipu Macsvanszyju da je ta odredba potjecala još iz vremena početka ratnoga stanja, pa kako je Financijalno ravnateljstvo već tada poslalo Vojnom zapovjedništvu popis osoba koje su bile poznate kao krijumčari, i to u smjeru Srbije, upozorio je da su shodno tome iste osobe možda i uhodarski sumnjive zbog povezanosti sa stanovništvom Srbije, kao i zbog vještine ilegalnoga prijelaza granice. Financijalno ravnateljstvo pitalo je bana drži li, s obzirom na uputu ugarskoga ministra financija, da ono treba nešto dalje poduzeti, pri čemu je valjalo imati na umu da bi se pri davanju uputa podređenim organima moglo uslijed prevelike revnosti nehotice dogoditi da nastane nepotrebno dopisivanje. Sam ravnatelj priopćio je Skerleczu da je za početak o uspostavi SDDS-a obavijestio kotarska financijalna ravnateljstva u Vukovaru, Gospiću i Ogulinu kao najbliža ratnim zonama. ${ }^{54} \mathrm{Na}$ pitanje banu Financijalnom ravnateljstvu odgovorilo je Vojno zapovjedništvo Zagreb, koje je držalo poželjnim da Ravnateljstvo „civilnoj doglasnoj postaji Zagreb" (SDDS-u) dojavi imena onih osoba koje su prema saznanjima financijalne službe do tada bile sumnjive da bi ih SDDS mogao ubuduće imati u vidu te da nastave tako postupati. ${ }^{55}$

Za početak je samo Vojno zapovjedništvo Zagreb dostavilo SDDS-u 14. listopada 1915. popis osoba koje su već bile evidentirane kao krijumčari iz Srbije ili u Srbiju. Tako je za kotar Zemun bilo zabilježeno 126 poznatih krijumčara, dopunjeno s još 15, za kotar Ruma 104 osobe, a za kotar Mitrovica 69 osoba, dopunjeno s još $27 .{ }^{56}$ Financijalni ravnatelj izvijestio je 2. listopada 1915. bana da su osobe zabilježene na listama kao krijumčari, ako su ujedno bile i politički nepouzdane, već odstranjene s tih područja početkom rata po vojnim vlastima - tj. internirane.$^{57}$ Financijalno ravnateljstvo nastavilo je do kraja rata postupati u skladu sa zahtjevima SDDS-a za područje Hrvatske i Slavonije.

Spomenimo da su još od 1914. i osnutka Defenzivno doglasne službe njezina sva četiri središnja ureda - cislajtanijski, ugarski, hrvatski i bosanskoherecegovački - bila formalnopravno ravnopravno postavljena, a Evidenzbureau ih je koordinirao i nadzirao. Razlozi te svojevrsne federalističke ravnopravnosti bili su dominantno funkcionalni, kao što je i njemački uveden za međusobnu komunikaciju kao radni jezik radi brzine izvješćivanja o sigurnosnim događajima te žurne analize i reakcije. No, manje je poznato da je tijekom svibnja 1915. načelnik Glavnoga stožera general Conrad po ulasku Italije u rat, želeći Monarhiju ugroženu izvana trima otvorenim bojištima ojačati tako da

\footnotetext{
54 HR-HDA-79-UOZV, SDDS, kut. 5695, spis 1504/15, dok. br. 1768.

55 HR-HDA-79-UOZV, SDDS, kut. 5695, spis 1504/15, dok. br. 53.

${ }^{56}$ HR-HDA-79-UOZV, SDDS, kut. 5695, spis 2350/15 (uloženo u spis 1504/15), dok. br. 1521.

${ }^{57}$ HR-HDA-79-UOZV, SDDS, kut. 5695, spis 2225/15 (uloženo u spis 1504/15), dok. br. 2237.
} 
ju konsolidira iznutra, vladarevu Vojnom uredu pismeno predložio državnu reformu..$^{58}$ Monarhiju je trebalo federalizirati i stvoriti središnji jedinstveni parlament. Pritom je osobito naglasio potrebu prestanka ugarskoga gušenja prava nemađarskih naroda, izrijekom zatražio poboljšanje položaja Hrvata, a želio je pored njemačkoga uvesti i češki kao drugi službeni jezik u Češkoj, čime bi se stvarno poboljšao i položaj češkoga naroda, neovisno o tome što se zbog problematične sigurnosne situacije Conrad zalagao i za vojnu osobu kao češkoga zemaljskog namjesnika. Predložio je i separatni mir sa Srbijom. Car i kralj Franjo Josip pozvao ga je zato u audijenciju 18. lipnja 1915., u međuvremenu obavljajući konzultacije s političarima, među njima i neizostavnim Tiszom, koji se usprotivio takvoj ideji zajedno s dijelom cislajtanijskih političara, pobornika velikonjemačke ideje.$^{59}$ Nakon audijencije kod cara, ${ }^{60}$ očito

${ }^{58}$ I prije Prvoga svjetskog rata, već u vrijeme pripreme aneksije Bosne i Hercegovine, iz vojnoga vrha bilo je prijedloga za reformu Monarhije. Tako je general Conrad 10. ožujka 1908. u audijenciji kod cara i kralja Franje Josipa predložio imenovanje vojne osobe povjerenikom za bansku Hrvatsku, a 1. travnja 1908. general Moritz Auffenberg (tada glavni inspektor vojnih časničkih škola, poslije ministar rata, bio je i zapovjednikom zagrebačkoga XIII. zbora te kao takav dobar poznavatelj lokalnih prilika) predložio je donošenje zakona o iznimnim mjerama za bansku Hrvatsku. Po njegovu donošenju iznimne mjere proglasile bi se zbog aneksijske krize, a vladin povjerenik oslonio bi se na frankovce. U ožujku 1909. Auffenberg je savjetovao načelniku Glavnoga stožera da se u slučaju izbijanja rata između Austro-Ugarske i Srbije svakako imenuje generala za vladina povjerenika u banskoj Hrvatskoj, ali istodobno i u Bosni i Hercegovini, s time da se po završetku rata ta dva mjesta spoje u jednoj osobi, nakon čega bi slijedio i državni preustroj, olakšan već spojenim funkcijama izvršne vlasti. Nacrt zakona zaista je bio izrađen, no nije donesen zbog smirivanja aneksijske krize, a general Svetozar Borojević razmišljao je o mjestu bana „Velike Hrvatske”. SUPPAN, Oblikovanje nacije u građanskoj Hrvatskoj, 205, bilj. 158 i 287. Neovisno o generalima, još godinu prije donošenja odluke o aneksiji Bosne i Hercegovine austrougarski ministar vanjskih poslova Alois Aehrenthal, promišljajući aneksiju, predložio je ministrima predsjednicima Cislajtanije Maxu Becku i Translajtanije Sándoru Wekerleu reformu Monarhije smatrajući, slično generalima, da će postići viši stupanj jedinstva Austro-Ugarske rješavajući glavne unutarnjopolitičke probleme afirmacijom nacionalnoga pitanja podređenih naroda, čime bi se ostvarila konsolidacija koja bi vanjskoj politici - vojsci i diplomaciji - pružila širu mogućnost djelovanja. U tom smislu predložio je: 1) priključenje okupiranih prostora Bosne i Hercegovine Monarhiji da bi se stvorila protuteža aktivnosti velikosrpske propagande koja je dolazila iz Beograda, nadajući se prilagodbi nacionalnih težnji Hrvata i monarhijskih Srba i politike novoga kursa interesima Monarhije uvođenjem općega izbornog prava u Ugarskoj, pa onda i u banskoj Hrvatskoj, očekujući potom konfrontaciju Hrvata i monarhijskih Srba sa Srbijom i Crnom Gorom, 2) stvaranje južnoslavenske državne zajednice kao samostalnoga tijela, ali u okviru Krune sv. Stjepana (u zajednicu je uključio Hrvatsku, Slavoniju, Dalmaciju i Bosnu i Hercegovinu) i 3) kao kompenzaciju za Dalmaciju, koju bi Austrija u tom slučaju izgubila, od Ugarske bi zatražio gospodarski savez s Austrijom trajno ili najmanje na rok od 25 godina, što bi značilo jedinstveno tržište i carinsku uniju. Ujedno je namjeravao dio ratne mornarice dodijeliti Ugarskoj nadajući se da bi tako potaknuo njezinu aktivniju ulogu na Jadranu, kao i u politici prema Italiji. Provedbom aneksije i rješavanjem aneksijske krize u korist Austro-Ugarske na miran način od tih se planova odustalo te je samo djelomično ostvaren Aehrenthalov prvi prijedlog - aneksija Bosne i Hercegovine. SUPPAN, Oblikovanje nacije u građanskoj Hrvatskoj, 293.

${ }^{59} \mathrm{~S}$ austrijskoga je gledišta velikonjemačka ideja podrazumijevala svenjemačko ujedinjenje, uključujući austrijske Nijemce, pri čemu bi glavni grad takve Njemačke bio Beč.

${ }^{60}$ Horvat slikovito opisuje da Franjo Josip nakon postizanja Austro-ugarske nagodbe te potom poraza u vanjskoj politici - bitke kod Solferina 1866. (gubitka talijanskih provincija) i krunidbe pruskoga kralja Vilima Hohenzollerna za njemačkoga cara 1871. (a time trajnoga smanje- 
prekoren, Conrad više nije potezao pitanje reforme premda njezina potreba nije uminula. ${ }^{61}$

Unatoč svemu poduzetom, daljnji razvoj događaja nije omogućio SDDS-u i sigurnosnom sustavu učinkovitu zaštitu nacionalne sigurnosti banske Hrvatske i Austro-Ugarske jer je za to bilo potrebno pravodobno donošenje političkih odluka visoke razine, za što je iz različitih razloga nedostajalo volje ili su motivi ključnih protagonista bili čak suprotni, no njihova razmatranja izlazila bi iz fokusa ovoga rada.

\section{Zaključak}

Politički razlozi preustroja sigurnosnoga sustava banske Hrvatske 1915. ogledali su se u želji njezinih civilnih vlasti, a time i Ugarske, da u većoj mjeri stave pod svoju kontrolu Središnju defenzivno doglasnu službu, koja je bila previše bliska vojnim vlastima, čime je ugrožavala rad Hrvatsko-srpske koalicije, a time i ugarsku dominaciju u banskoj Hrvatskoj. Za većinu istaknutih članova Koalicije moglo bi se pouzdano reći da su sve do izbijanja rata, koji je među ostalim izbio i zbog srbijanskih težnji za ostvarenjem velikosrpskoga nacionalno-političkog programa, bili u nezakonitoj vezi s institucijama koje su nedvojbeno počivale na velikosrpskim temeljima. Civilna vlast u Hrvatskoj na osnovi tih veza ne samo da nije pokretala veleizdajničke parnice, nego osumnjičene nije htjela pozvati ni na političku odgovornost i odreći se kompromitirane Koalicije. Umjesto toga intervenirala je u korist osumnjičenih da bi spriječila raspad Koalicije, koja je bila jamac režimu da će banska Hrvatska ostati pod gospodarsko-političkom dominacijom Ugarske, makar time bila ugrožena državna sigurnost cijele Monarhije. Funkcionalni razlozi preustroja odnosili su se na želju za postizanjem boljih rezultata rada sigurnosnoga sustava, bolje prikrivanje rada SDDS-a kao tajne službe unutar vladinih institucija te pružanje asistencije SDDS-u preko detektiva pograničnoga redarstvenog satništva i drugih redarstvenih povjereništava, kao i osiguravanje financijskih sredstava za redovni rad službe iz državnoga proračuna i vojnih dotacija za operativne zadatke.

Preustrojem, praćenim promjenom zagrebačkoga vojnog zapovjednika, Koalicija i ugarske vlasti samo su djelomično uspjele u svojim planovima jer premda je SDDS postao sastavnicom Zemaljske vlade, zadržao je funkcionalnu neovisnost, odnosno dvostruku odgovornost svojega upravitelja - i banu i Evidenzbureauu, pri čemu je počeo primati i vojne dotacije. Preustroj je pratila i uspostava dotad nepostojeće suradnje između Financijalnoga ravnateljstva u banskoj Hrvatskoj, koje je prema Hrvatsko-ugarskoj nagodbi formalno bilo

nja austrijskoga utjecaja u njemačkim zemljama), čemu možemo pridružiti i osobne tragedije (smrt sina i supruge) - nije više imao ni volje ni snage za bilo kakve radikalne promjene, pa mu je primjerenije geslo kao vladaru za poznu životnu dob bilo quieta non movere (lat. što je mirno, ne pomiči), a ne viribus unitis (lat. zajedničkim snagama). HORVAT, Hrvatski panoptikum, 65.

${ }^{61}$ RAUCHENSTEINER, The First World War, 426-434. 
podređeno vladi u Budimpešti, i SDDS-a u Zagrebu kao sastavnici Zemaljske vlade u razmjeni podataka na imperativni vojni zahtjev radi poboljšanja sigurnosti za vrijeme rata. Time je banska Hrvatska zahvaljujući vojnim potrebama došla korak bliže integraciji i proširenju funkcija autonomne vlasti na svojem području.

\section{Arhivsko gradivo}

HR-HDA: Hrvatska, Hrvatski državni arhiv, Zagreb:

- fond 78-PRZV: Zemaljska vlada. Predsjedništvo.

- fond 79-UOZV: Zemaljska vlada. Odjel za unutarnje poslove.

- fond 1363, bivši Arhiv Instituta za historiju radničkog pokreta, grupa XXI (Politička situacija).

- fond 1773, Osobni fond generala Stjepana Sarkotića.

\section{Novine}

Hrvatsko pravo (Zagreb), 1908.

Wiener Allgemeine Zeitung (Beč), 1908.

\section{Literatura}

BEUC, Ivan. Povijest institucija državne vlasti Kraljevine Hrvatske, Slavonije i Dalmacije. Zagreb: Pravni fakultet, Centar za stručno usavršavanje i suradnju s udruženim radom, 1985.

BILANDŽIĆ, Dušan. Hrvatska moderna povijest. Zagreb: Golden marketing, 1999.

BULIĆ, Ivan. Ivan Skerlecz Lomnički 1913-1917. Kraljevski komesar i hrvatski ban. Doktorska disertacija, Sveučilište u Zagrebu, 2011.

BULIĆ, Ivan. „Politika Hrvatsko-srpske koalicije uoči Prvoga svjetskog rata”. Časopis za suvremenu povijest 44 (2012), br. 2: 415-453.

BULIĆ, Ivan. „Savez Hrvatsko-srpske koalicije i bana Ivana Skerlecza u upravljanju Hrvatskom u vrijeme Prvoga svjetskog rata - značaj i posljedice”. U: Godina 1918. Prethodnice, zbivanja, posljedice, ur. Zlatko Matijević. Zagreb: Hrvatski institut za povijest, 2010, 23-47.

ČUTURA, Dinko. Sarkotić - časnik, strateg i političar. Doktorska disertacija, Sveučilište u Zagrebu, 2012.

DEDIJER, Vladimir. Sarajevo 1914 (I-II), Beograd 1977 (2. izdanje).

ĐORĐEVIĆ, Dimitrije. „Pokušaji srpsko-ugarske saradnje i zajedničke akcije 1906. godine”. U: Istorija XX veka. Zbornik radova, sv. II, ur. Dragoslav 
Janković. Beograd: Institut društvenih nauka, Odeljenje za istorijske nauke, 1961, 353-384.

GABELICA, Mislav. „Političke prilike u Banskoj Hrvatskoj na početku Prvoga svjetskog rata”. Društvena istraživanja 23 (2014), br. 1: 177-197.

GABELICA, Mislav. „Zagrebačka veleizdajnička parnica 1909. godine”. Časopis za suvremenu povijest 46 (2014), br. 1: 131-157.

GANZA-ARAS, Tereza. Politika "novog kursa” dalmatinskih pravaša oko Supila i Trumbića. Split: Matica hrvatska, 1992.

GROSS, Mirjana. „Hrvatska uoči aneksije Bosne i Hercegovine”. U: Istorija XX veka. Zbornik radova, sv. III, ur. Dragoslav Janković. Beograd: Institut društvenih nauka, Odeljenje za istorijske nauke, 1962, 153-269.

GROSS, Mirjana. Vladavina Hrvatsko-srpske koalicije 1906-1907. Beograd: Institut društvenih nauka, Odeljenje za istorijske nauke, 1960.

HORVAT, Josip. Hrvatski panoptikum. Zagreb: Globus, 1982.

HORVAT, Josip. Politička povijest Hrvatske, sv. I-II. Zagreb: August Cesarec, 1990.

JOVANOVIĆ, Slobodan. Vlada Aleksandra Obrenovića. Beograd: Izdavačka knjižarnica Gece Kona, 1929.

KOTA, Miroslav. „Uspostava i rad sigurnosno-obavještajnoga sustava banske Hrvatske 1914. godine”. U: 1914. Prva godina rata u Trojednoj Kraljevini i Austro-Ugarskoj Monarhiji, ur. Vijoleta Herman Kaurić. Zagreb: Matica hrvatska, 2018, 441-464.

KRIŠTO, Jure. Prešućena povijest. Katolička crkva u hrvatskoj politici 18501918. Zagreb: Hrvatska sveučilišna naklada, 1994.

KRIZMAN, Bogdan. Hrvatska u Prvom svjetskom ratu. Hrvatsko-srpski politički odnosi. Zagreb: Globus, 1989.

MACKENZIE, David. Apis, čovjek koji je izazvao Prvi svjetski rat. Sesvete: Profil knjiga, 2014.

MATIJEVIĆ, Zlatko. Između sna i jave. Rasprave o hrvatskoj političkoj povijesti 20. stoljeća. Zagreb: Golden marketing - Tehnička knjiga, 2016.

MATIJEVIĆ, Zlatko. Lučonoše ili herostrati? Prilozi poznavanju crkvenonacionalne povijesti Hrvata početkom XX. stoljeća. Zagreb: Erasmus naklada, 2006.

MATIJEVIĆ, Zlatko. Ljudi, stranke, događaji - prizori iz hrvatske političke povijesti. Zagreb: Golden marketing - Tehnička knjiga, 2019.

MATIJEVIĆ, Zlatko. U sjeni dvaju orlova. Prilozi crkveno-nacionalnoj povijesti Hrvata u prvim desetljećima 20. stoljeća. Zagreb: Golden marketing Tehnička knjiga, 2005.

MATKOVIĆ, Hrvoje, ur. Svetozar Pribićević. Izabrani politički spisi. Zagreb: Golden marketing; Narodne novine, 2000. 
MATKOVIĆ, Stjepan. Čista stranka prava 1895.-1903. Zagreb: Hrvatski institut za povijest, 2001.

MORITZ, Verena; LEIDINGER, Hannes; JAGSCHITZ, Gerhard. Im Zentrum der Macht. Die vielen Gesichter des Geheimdienstchefs Maximilian Ronge. Beč: Residenz Verlag, 2007.

MUŽIĆ, Ivan. Masonstvo u Hrvata. Zagreb: Matica hrvatska, 1989.

NENEZIĆ, Zoran D. Masoni u Jugoslaviji (1764-1980): pregled istorije slobodnog zidarstva u Jugoslaviji: prilozi i građa, Beograd, Autorsko-izdavačka grupa Zodne, 1988.

PETHÖ, Albert. Agenten für den Doppeladler: Österreich-Ungarns Geheimer Dienst im Weltkrieg. Graz: Leopold Stocker Verlag, 1998.

PILAR, Ivo [alias SÜDLAND, L. v.]. Južnoslavensko pitanje. Prikaz cjelokupnog pitanja, 2. izdanje. Varaždin: Hrvatska demokratska stranka, 1990 [pretisak 2. izdanja].

PRIBIĆEVIĆ, Adam. Moj život. Zagreb: Srpsko kulturno društvo „Prosvjeta", 1999.

PRIBIĆEVIĆ, Svetozar. Diktatura kralja Aleksandra. Zagreb: Globus, 1990.

RAUCH, Pavao. Memoari bana Pavla Raucha, ur. Branka Molnar, Zagreb: Zagrebačko arhivističko društvo, 2009.

RAUCHENSTEINER, Manfried. The First World War and the End of Habsburg Monarchy. Wien; Köln; Weimar: Böhlau Verlag, 2014.

RONGE, Max. Kriegs- und Industrie Spionage. Zürich; Leipzig; Wien, 1930.

STANIŠIĆ, Biserka. „Odsjek IV-B res. za pogranična redarstvena satništva Odjela za unutarnje poslove Kraljevske hrvatsko-slavonsko-dalmatinske zemaljske vlade u Zagrebu”. Arhivski vjesnik 36 (1993): 181-206.

Stenografski zapisnik o glavnoj raspravi protiv Adama Pribićevića i 52 druga, sv. XI. Zagreb: Naklada Kr. zemaljske tiskare, 1909.

SUPPAN, Arnold. Oblikovanje nacije u građanskoj Hrvatskoj (1835-1918.). Zagreb: Naprijed, 1999.

ŠIDAK, Jaroslav. „Hrvatsko pitanje u Habsburškoj monarhiji I i II”. Historijski pregled IX (1963), br. 2: 101-121 i br. 3: 175-194.

ŠIDAK, Jaroslav. „Jugoslavenska ideja u hrvatskoj politici do I. svjetskog rata”. U: Studije iz hrvatske povijesti XIX. stoljeća. Zagreb: Institut za historiju radničkog pokreta, 1973, 65-84.

ŠÖMEN, Branko. Amenkamen - slobodnozidarska čitanka. Zagreb: Lumen, 2001.

ŠÖMEN, Branko. Povijest slobodnog zidarstva u Hrvatskoj (I-III). Zagreb: Profil knjiga, 2012-2017.

ŠURMIN, Đuro. Vojska i hrvatska politika 1915. Zagreb, 1932. 
VALENTIĆ, Mirko; ČORALIĆ, Lovorka, ur. Povijest Hrvata, knj. 2: Od kraja 15. stoljeća do kraja Prvoga svjetskog rata. Zagreb: Školska knjiga, 2005.

VASIĆ, Dragiša. Devetstotreća (majski prevrat), Prilozi za istoriju Srbije od 8. jula 1900. do 17. januara 1907. Beograd: Izdanje i štampa štamparije Tucović, 1925.

VUCINICH, Wayne S. Serbia Between East and West, the Events of 19031908, Stanford: Stanford University Press, 1954.

WEST, Rebecca. Black Lamb and Grey Falcon, A Yourney through Yugoslavia. Edinburgh: Canongate Books, 2006. 


\section{SUMMARY}

\section{The Restructuring of Banal Croatia's State Security System in 1915}

During the second year of the Great War, the state security system of Banal Croatia was restructured to include the Central Counterintelligence Service (SDDS), which had previously functioned as a secret police, as an independent body of the Land Government. The SDDS became part of the newly established Department IV-B, responsible for border patrol units, under the Land Government's Internal Affairs Section. The reasons for this restructuring were of a political nature, specifically related to the conflict between military and civilian authorities, but also due to various functional reasons. Political reasons for the 1915 restructuring of Banal Croatia's security system reflected the aspirations of both its Croatian civilian authorities and Hungary to gain greater control over the SDDS, as it was growing too familiar with the military authorities, which put the work of the Croat-Serb Coalition, and therefore the Hungarian dominance over Banal Croatia, in jeopardy. In fact, a majority of the Coalition's distinguished members were illegally connected to the institutions that were unquestionably built on Greater Serbian ideals. The war itself was partially caused by Serbian aspirations to implement a Greater Serbian national-political programme. The Croatian civilian executive authorities not only avoided taking legal action against high treason, but also hesitated to bring the accused before the law for fear of losing the compromised Coalition. Instead, the civilian authorities would intervene in favour of the accused so as to prevent the crumbling of the Coalition, which was a guarantee to the regime that Banal Croatia would remain under Hungarian economic and political control, even if this endangered the entire Monarchy. The functional reasons for the restructuring were related to the aspirations of the military leaders to improve the security system, make the functioning of the SDDS better hidden within government institutions, and offer assistance to the SDDS via border police detectives and city police. It also wished to have the Service's work financed from the national budget and its operative work subsidised by the military. During the restructuring, the military commander of Zagreb was also replaced, but the Croat-Serb Coalition, acting in cooperation with the Hungarian authorities, was only partially successful in achieving their goals. The SDDS maintained its functional autonomy, i.e. dual responsibility to the ban (viceroy) and the Evidenzbureau, and started receiving military subsidies. Furthermore, due to the necessities of defence, the Land Government gained access to financial information that was previously unavailable as it fell outside the autonomy of Banal Croatia.

Key words: World War I; state security system; Banal Croatia; restructuring; Central Counterintelligence Service; Austria-Hungary 